\title{
The Consolidation of the Financial Services Industry: Causes, Consequences, and Implications for the Future
}

\author{
Allen N. Berger \\ Board of Governors of the Federal Reserve System \\ Washington, DC 20551 U.S.A. \\ and \\ Wharton Financial Institutions Center \\ Philadelphia, PA 19104 U.S.A. \\ Rebecca S. Demsetz \\ Federal Reserve Bank of New York \\ New York, NY 10045 \\ Philip E. Strahan \\ Federal Reserve Bank of New York \\ New York, NY 10045 \\ Forthcoming, \\ Journal of Banking and Finance \\ Volume 23, 1999
}

\begin{abstract}
$\underline{\text { Abstract }}$
This article designs a framework for evaluating the causes, consequences, and future implications of financial services industry consolidation, reviews the extant research literature within the context of this framework (over 250 references), and suggests fruitful avenues for future research. The evidence is consistent with increases in market power from some types of consolidation; improvements in profit efficiency and diversification of risks, but little or no cost efficiency improvement on average; relatively little effect on the availability of services to small customers; potential improvements in payments system efficiency; and potential costs on the financial system from increasing systemic risk or expanding the financial safety net.
\end{abstract}

JEL classification codes: G21, G28, G34, E58, L89

Key words: Banks, Mergers, Payments, Small business

The opinions expressed do not necessarily reflect those of the Federal Reserve Board, the New York Reserve Bank, or their staffs. We thank Bob Avery, Seth Bonime, Raphael Bostic, Steve Cecchetti, Dan Covitz, Dave Cummins, Bob DeYoung, Jeanette Donato, Diana Hancock, Tim Hannan, Iftekar Hasan, Dave Humphrey, Myron Kwast, Susan Leadem, Jamie McAndrews, Loretta Mester, Rick Mishkin, Linda Pitts, Matthew Porter, Robin Prager, Larry Radecki, Steve Rhoades, Tony Saunders, Greg Udell, Barbara Walter, and Eliza Wright for help with the article.

Please address correspondence to Allen N. Berger, Mail Stop 153, Federal Reserve Board, 20th and C Sts. NW, Washington, DC 20551, call 202-452-2903, fax 202-452-5295, or email aberger@frb.gov. 


\section{Introduction}

The financial services industry is consolidating around the globe. Mergers and acquisitions (M\&As) among financial institutions are occurring at a torrid pace in the U.S., may occur at a rapid pace in the near future in Europe under monetary union, and may be part of the solution to problems of financial distress in Asia and elsewhere. Moreover, we may be on the brink of a new wave of M\&As between large banking organizations and other types of financial service providers worldwide.

While there has been considerable research on financial services industry consolidation, much is yet to be understood. The main purposes of this article are to design a framework or model for evaluating the causes, consequences, and future implications of financial services industry consolidation, review the extant research literature within the context of this framework (over 250 references), and suggest fruitful avenues for future research.

In our framework, the main motivation behind consolidation is to maximize shareholder value, although we also consider the motives of other stakeholders, particularly managers and governments. Value may be maximized through M\&As primarily by increasing the participating firms' market power in setting prices or by improving their efficiency, and in some cases by increasing their access to the safety net.

Our framework predicts that the pace of consolidation will primarily be determined by changes in economic environments that alter the constraints faced by financial service firms. We identify five such changes that may be partially responsible for the recent rapid pace of consolidation - technological progress, improvements in financial condition, excess capacity or financial distress in the industry or market, international consolidation of markets, and deregulation of geographical or product restrictions.

The consequences of consolidation include not only the direct effects of increased market power or improved firm efficiency, but also some indirect effects. One potential indirect consequence may be a reduction in the availability of financial services to small customers. Potential systemic consequences of consolidation include changes in the efficiency of the payments system and changes in the safety and soundness of the financial system. In principle, policy makers may balance the expected social benefits and costs of these consequences in setting rules on consolidation or in approving/disapproving individual M\&As. In practice, however, it may be difficult to quantify these benefits and costs.

Our framework divides the research literature on the consequences of consolidation into two 
logically separable categories - static analyses and dynamic analyses. Static analyses are defined here to be studies that relate the potential consequences of consolidation to certain characteristics of financial institutions that are associated with consolidation, such as institution size. However, static studies do not use data on M\&As. These analyses are not necessarily intended to provide information about the effects of consolidation, but they nonetheless may prove useful in predicting the consequences of M\&As. For example, static analyses of scale efficiency may give valuable information as to the efficiency effects of M\&As in which the institutions substantially increase their size.

Dynamic analyses are defined here to be studies that compare the behavior of financial institutions before and after M\&As or compare the behavior of recently consolidated institutions with other institutions that have not recently engaged in M\&As. Dynamic analyses take into account that M\&As are dynamic events that may involve changes in organizational focus or managerial behavior. These analyses also incorporate any short-term costs of consummating the M\&A (legal expenses, consultant fees, severance pay, etc.) or disruptions due to downsizing, meshing of corporate cultures, or turf battles. Dynamic analyses are more inclusive than static analyses. For example, dynamic analyses of the efficiency consequences of consolidation include changes in X-efficiency (distance from optimal point on the best-practice efficient frontier) as well as the changes in scale, scope, and product mix efficiencies included in static analyses.

Our framework also emphasizes the importance of considering the external effects of consolidation, defined here as the reactions of other financial service providers to M\&As in their markets. The changes in competitive conditions created by M\&As may evoke significant reactions by rival firms in terms of their own organizational focus or managerial behavior that may either augment or offset the actions of the consolidating firms. For example, if consolidating institutions reduce their availability of credit to some small businesses, other institutions may pick up some of the dropped small business credits if it is value maximizing for them to do so. Only by including the external effects can the total effects of consolidation be determined.

Section 2 presents some "facts" of consolidation - summary statistics that provide background information for the discussion that follows. Section 3 reviews the causes of financial consolidation and identifies changes in the economic environment that may affect the pace of consolidation. Sections 4,5 , and 6 review the research literature on three potential consequences of consolidation-changes in market power, 
efficiency, and the availability of services to small customers, respectively. Section 7 addresses two potential systemic consequences of consolidation, changes in payments system efficiency and financial system safety and soundness. Section 8 extrapolates from the extant research to draw implications for future consolidation and for future research.

\section{The "facts" of financial consolidation}

Tables 1-5 report aggregate statistics on trends in financial consolidation. As shown in Table 1, the number of U.S. banks and banking organizations (stand-alone banks and top-tier bank holding companies (BHCs)) both fell by almost 30\% between 1988 and 1997. During this period, the share of total nationwide assets held by the largest eight banking organizations rose from $22.3 \%$ to $35.5 \%$. We also look at measures of concentration at the local level — defined as a Metropolitan Statistical Area (MSA) or non-MSA county — given the evidence discussed below that markets for most retail banking products are local. Despite all the consolidation activity, the average local market deposit Herfindahl index actually declined slightly over the period, falling by about $4 \%$ for MSAs and by about $5 \%$ for non-MSA counties. Total bank offices rose by $16.8 \%$, although total bank plus thrift offices declined by $0.1 \%$ in part because banks acquired branches formerly owned by failed thrifts.

Structural changes in the U.S. banking industry from M\&As, de novo entry, and failure are shown in Table 2. Several hundred M\&As occurred each year, about half of the in-market type and half of the market-extension type. During this period, "megamergers" - M\&As between institutions with assets over $\$ 1$ billion each - became common, most of them occurring between institutions in different states. Although not shown in the table, some very recent M\&As in the U.S. and elsewhere have increased dramatically in size, some reaching the scale of "supermegamergers" - M\&As between institutions with assets over $\$ 100$ billion each. Based on market values, nine of the ten largest M\&As in U.S. history in any industry occurred during 1998, and four of these - Citicorp-Travelers, BankAmerica-NationsBank, Banc One-First Chicago and Norwest-Wells Fargo — occurred in banking (Moore and Siems, 1998). In addition, the recent UBS-Swiss Bank Corp. supermegamerger created the largest bank in Europe.

Other changes in industry structure occurred as high rates of failure reduced the number of banks while high rates of de novo entry increased the number of banks. During the latter part of the 1980s, each 
year about 200 banks failed and about 200 new banks were formed (although the de novo banks were generally much smaller than the failed banks). Both failure and entry declined in the early 1990 s, while rates of entry picked up in the mid-1990s as industry profitability rose.

Table 3 gives data for U.S. nonbank financial institutions. The life insurance, property-liability insurance, and securities brokerage industries have changed much less than banking. The securities and life insurance segments were somewhat less concentrated in the mid-1990s than in the late 1980s, while the property-liability insurance segment was somewhat more concentrated. There was a substantial reduction in the number of thrift institutions and a corresponding increase in concentration due to the high rate of thrift failure in the late 1980s and early 1990s. The credit union industry remains very unconcentrated, presumably because of its not-for-profit status and because its members must have a "common bond," such as employment at the same firm.

Panel A of Table 4 reports the flow of domestic M\&A activity within the U.S. (columns 1-3) and within individual European nations (columns 4-6). The values shown are the sum of the market values of all target institutions over 1985-1997, and the percentages of the U.S. or European activity these represent. In the U.S., $51.8 \%$ of financial M\&A activity came from banks consolidating with other banks. Consolidation across sectors in the U.S. (the off-diagonal elements of the matrix in the first 3 columns) has been relatively uncommon, only $13.4 \%$ of the activity. In Europe, consolidation across sectors was more important, $37.5 \%$ of domestic M\&A activity.

Panel B of Table 4 reports international M\&A activity between U.S. and non-U.S. institutions (columns 1-3), between institutions operating in different European nations (columns 4-6), and between European and non-European financial institutions (columns 7-9). As was the case for the domestic M\&As, international M\&As within sectors exceeds M\&As across sectors, but the across-sector M\&As are relatively more important for European institutions. A comparison of panels A and B indicates that for U.S. institutions, domestic M\&As dominate international M\&As for banks, securities firms, and insurers by large margins. For Europe, domestic banking M\&As dominate international M\&As, but this is not true for the securities and insurance industries. For these two industries, the combination of intra-Europe and Europenon-Europe M\&As in panel B exceeds the within-nation M\&As in Europe in panel A. 
Table 5 compares the structure of depository institutions in the eleven G-10 countries in 1996. The U.S. has a much more fragmented industry than in any other developed country — almost 10,000 more institutions than the other 10 nations combined. Table 5 also suggests that the U.S. is not "overbranched" relative to other developed countries - the 2,772 inhabitants per office in the U.S. is the highest of all of the G-10 countries.

\section{The causes of financial consolidation}

In our framework, the primary motive for consolidation is maximizing shareholder value. In the absence of capital market frictions, all actions by the firm, including consolidation activities, would be geared toward maximizing the value of shares owned by existing shareholders. The preferences of other stakeholders would be taken into account only in so far as they affected the value of shares through the cost of funds, supply of labor or other factors of production, or the demand for services. In practice, however, managers and government often affect consolidation decisions more directly.

In this section, we outline and review the literature on the value maximizing and non-value maximizing motives for financial consolidation. We then identify five types of changes in the economic environment that may have led to the recent accelerated pace of consolidation.

\subsection{The value-maximization motive}

Financial service firms can maximize value in one of two main ways through consolidation — by increasing their market power in setting prices or by increasing their efficiency. It is difficult to determine the goals of M\&A participants, but there is evidence consistent with the notion that some M\&As are designed to increase market power. Research described in Section 4 below suggests that in-market M\&As that substantially increase market concentration may increase market power in setting prices on retail services. Presumably, this was an expected consequence of many of these M\&As and provided at least part of the motivation. Also supporting this presumption are the findings that about half of the U.S. bank M\&As are in-market (Table 2) and many European bank M\&As are of this type as well (Vander Vennet 1997).

Research described in Section 5 below also suggests that M\&As may increase efficiency, consistent with the presumption that expected efficiency improvements provide part of the motivation for M\&As. In addition, a number of studies have found that in a substantial proportion of M\&As, a larger, more efficient 
institution tends to take over a smaller, less efficient institution, presumably at least in part to spread the expertise or operating policies and procedures of the more efficient institution over additional resources. In the U.S., acquiring banks appear to be more cost efficient than target banks on average (Berger and Humphrey 1992, Pilloff and Santomero 1998). Another study of U.S. banks found that acquiring banks are more profitable and have smaller nonperforming loan ratios than targets (Peristiani 1993). Simulation evidence also suggests that large X-efficiency gains are possible if the best practice banks merge and reform the practices of the least efficient banks (Savage 1991, Shaffer 1993). Case studies of U.S. bank M\&As support the idea that potential efficiency gains act to motivate some M\&As as well (Calomiris and Karceski 1998, Rhoades 1998). However, one study of U.S. banks found that while poorly-capitalized banks are more likely to be acquired, banks with a high degree of cost inefficiency are, ceteris paribus, less likely to be acquired without government assistance (Wheelock and Wilson 1998).

European studies also suggest that M\&As may be motivated in part by the potential for efficiency gains. One study found that large, profitable banks tend to be acquirers, while small, unprofitable banks tend to be targets (Focarelli, Panetta, and Salleo 1998), while another found that large, efficient banks tend to acquire small, less efficient banks (Vander Vennet 1997). Similar potential for improvements were possible in M\&As between UK banks and building societies (Altunbas, Maude, and Molyneux 1995).

Some evidence also suggests that efficiency concerns may motivate consolidation in other segments of the financial industry. Acquirers in the U.S. life insurance industry tend to be more efficient than average, and targets tend to be financially impaired (Cummins, Tennyson, and Weiss 1999). In the credit union industry, acquirers tend to be larger than average, while targets tend to be smaller and in weaker financial condition than non-target credit unions (Fried, Lovell and Yaisawarng 1999).

Efficiency (as broadly defined here) may also be improved by M\&As if greater diversification improves the risk-expected return tradeoff. Consistent with this idea, one study found that U.S. acquiring banks bid more for targets when the consummation of the M\&A would lead to significant diversification gains (Benston, Hunter and Wall 1995). Diversifying M\&As may also improve efficiency in the long term through expanding the skill set of managers (Milbourn, Boot and Thakor 1999). However, studies outside of financial services suggest that diversifying M\&As are generally value-reducing, and that increases in 
corporate focus are value-enhancing (Lang and Stulz 1994, Berger and Ofek 1995, John and Ofek 1995).

In addition, although it is not exactly market power or efficiency, some institutions may try to increase the value of their access to the government's financial safety net (including deposit insurance, discount window access, payments system guarantees) through consolidation. ${ }^{\prime}$ If financial market participants perceive very large organizations to be "too big to fail" - i.e., that explicit or implicit government guarantees will protect debtholders or shareholders of these organizations - there may be incentives to increase size through consolidation, lower the cost of funding, and increasing the value of shares. International comparisons over a 100-year period show how changes in the structure and strength of safety net guarantees may affect financial institution risk-taking, and by extension, the motive to consolidate to increase the value of access to the safety net (Saunders and Wilson 1999). As discussed in Section 7 below, the net subsidy from the safety net may also be extended when banking organizations are consolidated with other types of institutions.

\subsection{Non-value maximizing motives}

As noted above, stakeholders other than shareholders may have a direct effect on consolidation decisions. We consider here the roles of managers and governments, who appear to have more influence over consolidation decisions for financial institutions than for nonfinancial firms. ${ }^{2}$

\subsubsection{The role of managers}

Managers may be able to pursue their own objectives in consolidation decisions, particularly in banking where corporate control may be relatively weak. Banking regulations in the U.S. weaken the corporate control market by generally allowing only other banks and BHCs to acquire a bank. The regulatory approval/disapproval process may also deter some acquirers. In addition, most U.S. banks are small and are not publicly traded. Perhaps as a result of these conditions, hostile takeovers that replace management are rare in U.S. banking (Prowse 1997). However, corporate control appears to improve when intrastate and

${ }^{1}$ Regulators may also help protect large financial institutions by encouraging other institutions to lend to or invest in a financially distressed institution.

${ }^{2}$ Debtholders may play a lesser role in the consolidation decisions of financial institutions than nonfinancial firms. This is because financial institution debtholders may be protected in whole or in part by the safety net, and by government supervision which tends to block M\&As that create substantial risks. 
interstate banking deregulation increases the number of potential acquirers, which has been found to increase market discipline, reduce the market share of poorly run banks, and generally raise profitability (Schranz 1993, Hubbard and Palia 1995, Jayaratne and Strahan 1996,1998).

One managerial objective may be empire-building. Executive compensation tends to increase with firm size, so managers may hope to achieve personal financial gains by engaging in M\&As, although at least in part the higher observed compensation of the managers of larger institutions rewards greater skill and effort. To protect their firm-specific human capital, some managers may also attempt to reduce insolvency risk below the level that is in shareholders' interest, perhaps by diversifying risk through M\&A activity.

There is evidence that banking organizations may overpay for acquisitions when corporate governance structures are not sufficiently well-designed to align managerial incentives with those of owners. For example, banks that have addressed managerial agency problems through high levels of managerial shareholdings and/or concentrated ownership experience higher (or less negative) abnormal returns when they become acquirers than banks that have not addressed these agency conflicts as well. In addition, abnormal returns at bidder banks are increasing in the sensitivity of the CEO's pay to the performance of the firm and to the share of outsiders on the board of directors (Allen and Ceboyan 1991, Subrahmanyam, Rangan and Rosenstein 1997, Cornett, Hovakimian, Palia and Tehranian 1998). This evidence suggests that entrenched managers with little pay sensitivity to performance or outside directors may make acquisitions that do not maximize shareholder wealth.

Managerial entrenchment may also prevent some value maximizing M\&As by reducing the willingness of some financial institutions to become targets of M\&As. One study found that banks in which managers hold a greater share of the stock are less likely to be acquired and that this effect is much larger at banks where management leaves following an acquisition (Hadlock, Houston, and Ryngaert 1999). This is consistent with the idea that management teams with large ownership stakes can block outside acquisitions.

\subsubsection{The role of government}

The government plays a direct role in consolidation decisions through restricting the types of M\&As permitted (e.g., limits on interstate or international M\&As, or M\&As between banks and other firms), and through approval/disapproval decisions for individual M\&As. In part, this is to limit the government's 
liability and prevent exploitation of "too big to fail" and expansion of the safety net, as described in Section 3.1 above. Regulatory review of bank M\&A applications in the U.S. attempts to prevent consolidation in which excessive increases in risk are expected. Regulators also prevent in-market M\&As if the increases in concentration are expected to result in excessive increases in market power. Regulators may block M\&As to promote other policy goals as well. For example, U.S. banking organizations may be prevented from making acquisitions if they do not meet the lending standards of the Community Reinvestment Act (CRA). ${ }^{3}$

In contrast to these restrictions on M\&As, government may also encourage consolidation (beyond the safety net incentive discussed above). During periods of financial crisis, the government may provide financial assistance or otherwise aid in the consolidation of troubled financial institutions. For example, the FDIC provided financial assistance to allow healthy banks to purchase over 1,000 insolvent U.S. banks between 1984 and 1991. In other nations, governments have acquired troubled institutions themselves.

\subsection{Why is consolidation accelerating?}

Our framework predicts that the pace of consolidation will primarily be determined by changes in economic environments that alter the constraints faced by financial service firms. A relaxation of constraints may allow consolidation that increases shareholder value or make it easier for managers to pursue their own goals through consolidation. We identify five key changes that may help explain the recent fast pace of M\&A activity - technological progress, improvements in financial condition, excess capacity/financial distress, international consolidation of markets, and deregulation.

\subsubsection{Technological progress}

Technological progress may have increased scale economies in producing financial services, creating opportunities to improve efficiency and increase value through consolidation. New tools of financial engineering, such as derivative contracts, off-balance-sheet guarantees, and risk management may be more efficiently produced by larger institutions. Some new delivery methods for depositor services, such as phone centers, ATMs, and on-line banking, may also exhibit greater economies of scale than traditional branching

${ }^{3}$ For a review of CRA issues, see Thomas (1998). Community advocates may reinforce this government motive by petitioning regulators to block proposed M\&As on these grounds. In some cases, consolidating banks make well-publicized pledges to provide credit to small businesses and make loans in low income neighborhoods during the regulatory approval/denial process. 
networks (Radecki, Wenninger, and Orlow 1997). As discussed in Section 7 below, advances in payments technology may also have created scale economies in back-office operations and network economies.

An important caveat is that technologies embodying scale economies may in some cases be accessed at low cost by small financial institutions. The new tools of financial engineering, advanced depositor delivery services, or payments technologies may be distributed to small financial institutions through correspondent banking systems, through franchising or outsourcing to firms specializing in the technologies, shared ownership or mandatory sharing of payments networks, etc. (discussed further in Section 7 below). ${ }^{4}$ Nonetheless, some evidence discussed in Section 5 below suggests that scale economies in banking have increased in the 1990s, consistent with technological progress that favors larger institutions.

\subsubsection{Improvements in financial condition}

Recent improvements in the financial condition of institutions may be another factor behind the increase in M\&As. In the U.S., bank profitability broke records in the mid-1990s. Low interest rates and high stock prices also reduced financing constraints on M\&A activity, although they raised the price of target firms as well. Evidence from outside banking suggests that financial condition can affect investment, although the reason why condition matters is less clear (Fazzari, Hubbard and Petersen 1988, Froot and Stein 1991, Hoshi, Kashyap, and Sharfstein 1991, Lamont 1996, Kaplan and Zingales 1997). One possibility is that external finance is more costly than internally generated funds, so firms may invest in more positive net present value projects when they are flush with cash. It is also possible that as more "free cash flow" becomes available, managers may choose to acquire other firms to suit their own goals (Jensen 1986). The data suggest that M\&A activity in banking appears to respond more to the low-interest rate and high stockprice environment of the U.S. in mid-1990s than M\&A activity in nonfinancial industries, despite the fact thạt stock deals are more common than cash acquisitions in banking (Esty, Narasimhan, and Tufano 1999).

\subsubsection{Accumulation of excess capacity or financial distress}

Consolidation may also be an efficient way to eliminate excess capacity that has arisen in the consolidating firms' industry or local market. When there is excess capacity, some firms may be below

${ }^{4}$ Despite economies in sharing technology, some institutions may keep their own information and back-office technologies to improve their future options for expansion into different activities (Thakor 1999). 
efficient scale, have an inefficient product mix, or be inside the efficient frontier. M\&As may help solve these efficiency problems. M\&As may also help remove excess capacity more efficiently than bankruptcy or other means of exit in part by preserving the preexisting franchise values of the merging firms.

There is some evidence of excess capacity problems arising for U.S. banks, which have lost market share to competing financial institutions on both sides of the balance sheet since the end of the 1970s. On the asset side, U.S. banks have lost a substantial proportion of corporate lending to foreign banks, other intermediaries, and capital markets, although they have made up for some of this lost business through offbalance sheet activities (Boyd and Gertler 1994, Berger, Kashyap and Scalise 1995). On the liability side, households now hold a greater share of their wealth outside of bank deposits as the supply of substitutes provided by competing financial institutions, such as mutual funds, has grown.

Consolidation may similarly be an efficient way of resolving problems of financial distress, which are not entirely distinct from excess capacity problems. Institutions that are troubled because of excess capacity in their industry or markets, their own inefficiency, or underperforming investments are often taken over as an efficient alternative to bankruptcy or other means of exit. The evidence cited in Section 3.1 above that target financial institutions tend to be relatively inefficient, have high nonperforming loan ratios, and have low capital ratios is consistent with financial distress motivating consolidation. ${ }^{5}$ As noted above, regulators may also act to spur consolidation in periods of financial crisis.

\subsubsection{International consolidation of markets}

The consolidation of financial service firms across national borders may also derive in part from the international consolidation of markets. The transfers of securities, goods, and services in international markets creates demands for currency, deposit, loan, and other services by international financial institutions. Thus, the globalization of markets has likely contributed to cross-border M\&As and the globalization of financial service firms, although the causation likely works in the other direction as well (Kwast 1996a, Meyer 1998).

\subsubsection{Deregulation}

${ }^{5}$ See Berger and Humphrey (1997) for a summary of evidence on the effects of inefficiency and nonperforming assets on the probability of financial institution failure. 
Restrictions on banks' ability to expand geographically were relaxed in the 1980 s and early 1990 s in the U.S. with a series of removals of restrictions on intrastate and interstate banking, concluding with the Riegle-Neal Interstate Banking and Branching Efficiency Act of 1994, which permits interstate branching in almost all states. ${ }^{6}$ The prior geographic restrictions on competition may have allowed some inefficient banks to survive. The removal of these constraints allowed some previously prohibited M\&As to occur, which may have forced inefficient banks to become more efficient by acquiring other institutions, by being acquired, or by improving management practices internally. ${ }^{?}$

The U.S. evidence suggests that consolidation accelerated as a result of deregulation. M\&A activity increased in states after they joined interstate banking agreements (Jayaratne and Strahan 1998). In addition, the percentage of deposits held by subsidiaries of out-of-state BHCs in the typical state expanded from $2 \%$ to $28 \%$ between 1979 and 1994 (Berger, Kashyap, and Scalise 1995). Removal of in-state branching restrictions also spurred consolidation in the U.S., as multibank BHCs often merged their subsidiary banks into branching systems. The deregulation also appeared to result in significant entry into local markets via de novo branching (Amel and Liang 1992, Calem 1994, McLaughlin 1995).

There has also been limited deregulation of restrictions on bank powers in the U.S. Restrictions on investment banking and other powers of commercial banking organizations were put in place by the Banking Act of 1933 (the Glass-Steagall Act), the Bank Holding Company Act of 1956 and its 1970 amendment. Liberalization of these powers began in 1987, when the Federal Reserve expanded BHCs' abilities to underwrite corporate debt and equity through "Section 20 " affiliates, but the revenue from such underwriting could not exceed $5 \%$ of the subsidiary's total revenue. This restriction was raised to $10 \%$ in 1989 , and then to $25 \%$ in $1996 .^{8}$ Following this last deregulation, Bankers Trust acquired Alex. Brown, Inc., BankAmerica

${ }^{6}$ See Berger, Kashyap, and Scalise (1995) for year-by-year details on the changes in state laws.

${ }^{7}$ Of course, deregulation is not strictly exogenous. The emergence of new technologies in both deposit taking and lending may have encouraged deregulation (Kroszner and Strahan 1997). Another impetus may have been the rash of bank and thrift failures in the 1980s, which increased awareness of the advantages of geographically diversified institutions (Kane 1996).

${ }^{8}$ As of 1996, BHCs' share of the U.S. corporate debt underwriting market was $16.3 \%$ of dollar volume or $20.4 \%$ of issues, while their share of corporate equity underwriting was $2.2 \%$ of dollar volume or $1.9 \%$ of issues (Gande, Puri, and Saunders 1998). 
acquired Robertson Stephens, NationsBank acquired Montgomery Securities, and Citicorp merged with Travelers, which owns Salomon/Smith Barney (Saunders 1999). ${ }^{9}$

Despite the geographic and bank powers deregulation, the remaining regulations likely will continue to restrain consolidation activity. The Riegle-Neal Act caps the total amount of insured deposits that any banking organization may reach by M\&A to $30 \%$ in a single state and $10 \%$ nationally. The 1998 BankAmerica-NationsBank M\&A created an institution with more than $8 \%$ of insured deposits in the U.S., so the ability of the consolidated institution to make further acquisitions may be limited. This cap may make it difficult for any banking organization to operate in all 50 states, although an institution may exceed the $10 \%$ cap through internal growth or may circumvent the restriction in part by using non-deposit funding or reduce the need for funding by moving assets off the balance sheet. The bank powers restrictions also appear to hamper consolidation. As of this writing, regulatory/legislative hurdles remain for the insurance underwriting component of the 1998 Citicorp-Travelers M\&A.

Europe has also been undergoing deregulation. The European Union banking directive has allowed banks to operate fairly freely across national boundaries in Europe since 1993 and the implementation of monetary union should also foster international M\&As. However, as indicated in Table 4 above, to date there has been little intra-Europe international consolidation of banks, although there has been considerable consolidation of other financial institutions. This suggests there may be other impediments to intra-Europe international bank consolidation, some of which are discussed in Section 8 below.

\section{Research on the Market Power Consequences of Consolidation}

\subsection{Background on market power}

M\&As among institutions that have significant local market overlap ex ante may increase local market concentration and allow the consolidated firm to raise profits by setting prices less favorable to customers. This may affect rates and fees on retail deposits and small business loans, as these products are typically competed for on a local basis. M\&As of the market-extension type that join institutions in different parts of a nation or in different nations are less likely to increase local market power.

\footnotetext{
${ }^{9} \mathrm{~A}$ recent event study found positive wealth effects of the 1987 liberalization, but negative wealth effects and positive measured risk effects of subsequent liberalizations (Bhargava and Fraser 1998).
} 
The focus on local markets is partly because of policy guidelines used in the M\&A approval/denial process in the U.S. (the cluster approach), partly because research discussed below finds that local market concentration is statistically significantly related to prices, and partly because research indicates that households and small businesses almost always choose a local financial institution (Kwast, Starr-McCluer, and Wolken 1997, Kwast 1999). Wholesale financial services, such as large corporate loans, derivative contracts, and group insurance products generally trade in national or international markets. It seems unlikely that consolidation would create substantial market power against the large clients for these services, who typically can choose among many suppliers. ${ }^{10}$

The static literature on market power usually examines the effects of local market concentration on financial institution profits and prices, but does not use information on M\&As, whereas the dynamic literature directly examines the profits and prices of firms that have recently engaged in M\&As. An issue in the market power research is whether statistical controls for efficiency are included. If efficiency is not controlled for, then the measured effects of market concentration or M\&As on prices or profits will be the combined effect of market power and efficiency, not the effect of market power alone. Another concern about the extant empirical evidence is that antitrust authorities often block, alter, or deter M\&As that are expected to result in substantial increases in market power. As a result, it may be difficult to find evidence of large gains in market power from M\&As, even if the potential for such gains exists.

\subsection{Static market power analyses - Effects of market concentration on prices and profits}

Most of the studies of the effects of local market concentration on prices and profits used data on U.S. banks from the 1980s, and defined local markets as MSAs or non-MSA counties. This research may give evidence on the static effects of in-market M\&As, which generally increase local market concentration. Studies usually found that banks in more concentrated markets charge higher rates on small business loans and pay lower rates on retail deposits (Berger and Hannan 1989,1997, Hannan 1991). This result generally held whether or not differences in efficiency were controlled for statistically. Other studies found that in more concentrated markets, bank deposit rates were "sticky" or slow to respond to changes in open-market

\footnotetext{
${ }^{10}$ One exception may be the market for clearing U.S. government securities, in which two banks serve most of the market.
} 
interest rates, and that this stickiness was greater with respect to rate increases than decreases, consistent with market power (Hannan and Berger 1991, Neumark and Sharpe 1992, Hannan 1994, Jackson 1997)."

Despite this evidence of market power by banks in the 1980s, there are some reasons to suspect that market power may have declined since that time. First, there may be an increase in the degree of contestability of financial services markets because the removal of geographic restrictions on banking organizations allow existing institutions to enter or threaten to enter more local markets. In addition, some financial services have become more like commodities, making competition more perfect than in the past (Santomero 1999). Moreover, changes in the delivery of financial services - such as ATM kiosks, telephone banking, on-line banking, expanded use of credit and debit cards, etc. - may also have made local markets more contestable and expanded their effective geographic size.

The empirical evidence on this issue is mixed. The relationship between local market concentration and deposit rates seems to have dissipated somewhat in the 1990s (Hannan 1997, Radecki 1998), although the relationship between local market concentration and small business loan pricing still appears to be strong (Cyrnak and Hannan 1998). ${ }^{12}$ The recent data also suggest that large banks often set uniform rates for deposits and loans over a state or region of a state rather than over a local market, although the reason for this is not clear (Radecki 1998). Bank fees on retail deposit and payments services in the 1990s show very little relationship with measures of local market concentration in the 1990s, consistent with relatively low market power (fee data are not available for the 1980s, Hannan 1998). However, multistate BHCs tend to charge higher fees to retail customers than other banks, suggesting that these firms may not be exerting competitive pressures on prices in local markets. In addition, the data are mixed as to whether contact

\footnotetext{
${ }^{11}$ Other tests for market power in the banking industry are unrelated to local market structure. Some studies have tested for price-taking versus price-setting behavior for banks, with some support for both positions (Hancock 1986, Shaffer 1989, English and Hayes 1991, Hannan and Liang 1993). Recent studies of revenue and profit functions generally found that an "alternative" specification in which firms choose output prices fit the data at least as well as the "standard" competitive markets specification in which firms choose output quantities in reaction to exogenous prices (Berger, Humphrey, and Pulley 1996, Berger and Mester 1997, Humphrey and Pulley 1997). In addition, studies of reserve requirements and rates on certificates of deposit suggest that banks do not pass through all of the costs of regulatory requirements to customers, implying that banks have market power (Fama 1985, Cosimano and McDonald 1998).

${ }^{12}$ In part, the changes in the measured effects of concentration on deposit rates may reflect changes in the survey instruments used to collect the rate data.
} 
between geographically dispersed financial institutions in multiple local markets results in more or less favorable prices for customers (Mester 1987,1992a, Pilloff 1997). ${ }^{13}$

Despite the findings of market power in bank pricing, the static literature usually found quite small effects of concentration on bank profits, especially after statistical controls for efficiency were included in the analyses (Berger 1995, Maudos 1996, Berger and Hannan 1997). ${ }^{14}$ Similarly, the banks that were found to have persistently high profits relative to the industry generally were not those in local markets with the highest concentration or with the greatest barriers to entry (Berger, Bonime, Covitz, and Hancock 1998). ${ }^{15}$ One possible explanation of how market power may have a much greater effect on prices than on profits is that managers of weakly controlled firms may take part of the benefits of the extra revenues as reduced effort to maximize efficiency, or a "quiet life" (Berger and Hannan 1998).

\subsection{Dynamic market power analyses - Effects of M\&As on prices and profits}

Dynamic market power analyses examine the effects of the M\&As themselves on prices and profits, incorporating any effects of changes in organizational focus or managerial behavior or transition costs of the M\&As, as well as the market concentration effects considered in the static literature.

One dynamic study of bank pricing found that bank M\&As that involve increases in market concentration severe enough to violate the U.S. Justice Department bank guidelines (Herfindahl over 1800, increase of over 200) substantially reduced the deposit rates paid by M\&A participants, consistent with

\footnotetext{
${ }^{13}$ There are other issues about market definition and competitiveness which we do not have space to discuss, such as whether thrifts should be included as competitors to banks in measuring concentration (Hannan and Liang 1995, Amel and Hannan 1998), whether concentration measures should include small business loans as well as deposits (Cyrnak and Hannan 1998), whether large and small banks are equally aggressive competitors (Pilloff 1998), and whether the cost to consumers of switching between institutions is a significant source of market power (Rhoades 1997, Sharpe 1997).

${ }^{14}$ Some of the early research on this topic controlled for market share, rather than efficiency, and debated whether market share better represented efficiency or market power. For examples in the banking literature, see Smirlock (1985) for arguments favoring efficiency and Rhoades (1985) for arguments favoring market power. For examples in the general industrial organization literature see Smirlock, Gilligan, and Marshall (1984, efficiency) and Shepherd (1986, market power).

${ }^{15}$ A related study also showed that high profitability from market power or other sources increased the probability of entry that subsequently lowered profits, but that this competitive process often did not occur and was relatively slow (Amel and Liang 1997).
} 
market power effects of M\&As (Prager and Hannan 1999). Another dynamic study that included a larger sample of M\&As - many of which did not involve substantial increases in market concentration — found that some M\&A categories lowered deposit rates and others raised deposit rates relative to what was predicted by the level of concentration (Simons and Stavins 1998). The more mixed results are not surprising, given the inclusion of M\&As for which substantial market power effects were not expected. Neither of these studies accounted explicitly for the efficiency effects of the M\&As, so their results give the combined effects of changes in market power and efficiency on prices and cannot disentangle the two effects. One other study did account for efficiency and found very small price changes and much larger efficiency changes for M\&As among large U.S. banking organizations, although this study did not focus on M\&As involving substantial increases in local market concentration (Akhavein, Berger, and Humphrey 1997). A study of Italian M\&As found that when there was market overlap and the market share of the acquired bank was small, loan rates declined, but this result was reversed when market share was large (Sapienza 1998).

A number of studies compared bank profitability ratios, such as the return on assets (ROA) or return on equity (ROE) before and after M\&As relative to peer groups of banks that did not engage in M\&As. Some found improved profitability ratios associated with M\&As (Cornett and Tehranian 1992, Spindt and Tarhan 1992, Rhoades 1998), although others found no improvement in these ratios (Berger and Humphrey 1992, Linder and Crane 1992, Pilloff 1996, Akhavein, Berger, and Humphrey 1997, Chamberlain 1998). A problem with drawing conclusions from profitability ratios is that they incorporate both changes in market power and changes in efficiency, which cannot be disentangled without controlling for efficiency.

Similarly, some dynamic studies have compared simple cost ratios, such as costs per dollar of assets, before and after M\&As (Rhoades 1986,1990,1998, Srinivasin 1992, Srinivasin and Wall 1992, Linder and Crane 1992, Pilloff 1996). Again, the problem of disentangling changes in market power from changes in efficiency arises. These studies did not control for input prices, and so a reduction in costs per unit of output or assets could reflect either lower interest expenses due to increased market power in setting deposit interest rates or greater efficiency in input usage. Some studies examined operating cost ratios that exclude interest expenses, and so would not be subject to this problem (Cornett and Tehranian 1992, Linder and Crane 1992, Srinivasan 1992, Srinivasan and Wall 1992, Rhoades 1998). However, these studies may be biased toward 
showing benefits from M\&As. As banks merge and grow larger, they often substitute interest cost-intensive purchased funds for operating cost-intensive core deposits, which would tend to make the operating cost ratio lower even if there is no decrease in total costs. Use of the cost ratios also does not account for the fact that some product mixes cost more to produce than others.

Several dynamic studies have employed event study and similar techniques to look at the effects of bank M\&As on market values. The change in the combined market value for the acquiring and acquired institutions together (adjusted using a market model for changes in overall stock market values) provides an estimate of the effect of the M\&A on the present value of future profits of the consolidated institution. As was the case for the profitability ratios, the results were mixed. Some studies found increases in the combined value around the times of M\&A announcements (Cornett and Tehranian 1992, Zhang 1995), others found no improvement in combined value (Hannan and Wolken 1989, Houston and Ryngaert 1994, Pilloff 1996), while still others found that the measured effects depended upon the method of financing chosen, the degree of office overlap, and other factors (Houston and Ryngaert 1996,1997, Siems 1996). A study of domestic and international M\&As involving U.S. banks found more value created by the international M\&As, although it also found that more concentrated geographic and activity focus had positive effects on value (DeLong 1998). A study of M\&As among banks and between banks and insurers in Europe found that many of the events increased combined value and attributed the differences in findings from many of the U.S. studies to differences in structure and regulation in Europe (Cybo-Ottone and Murgia 1998).

Interpretation of event studies is subject to a number of well known problems, including that information may have leaked prior to the M\&A announcement or that markets may anticipate M\&As prior to their announcements. These problems may be particularly severe during "merger waves," such as those that have been occurring in U.S. markets (Calomiris 1999). M\&A announcements may also incorporate signals about the underlying values of the consolidating firms in addition to the change in value created by M\&As. In addition, as was the case for the simple profit and cost ratios, there is no way to determine whether changes in market values are from changes in market power or efficiency, since markets evaluate expected changes in profitability from all sources equally.

\subsection{The external market power effect}


Recall that the total effects of M\&As also include the external effect - the reactions of other financial service providers in the same markets. It is expected that other firms would charge similar prices for similar products and so would change their prices by a like amount as the consolidating institutions when an M\&A results in a price change. The data are consistent with this expectation. The static findings regarding concentration above embody an external effect of consolidation on the market power of other firms in the local market, since their concentration is also increased by in-market M\&As. Two of the dynamic studies also found that prices of the rival banks in the same market changed by similar amounts and in the same direction as those of the consolidating institutions (Sapienza 1998, Prager and Hannan 1999).

\section{Research on the Efficiency Consequences of Consolidation}

\subsection{Background on efficiency}

Consolidation may increase or decrease efficiency in a number of different ways. M\&As may allow the institutions to achieve a scale, scope, or mix of output that is more profitable. Consolidation also may be a means to change organizational focus or managerial behavior to improve X-efficiency. Our broad definition of efficiency gains also includes improvements in the institution's risk-expected return tradeoff. Such gains may be particularly important in financial institution M\&As, which often offer the possibility of diversification gains through investing across regions, industries, etc. and/or through entering other industries. Reductions in risk may increase shareholder wealth because financial distress, bankruptcy, and loss of franchise value are costly, and because regulators may restrict activities or impose other costs as a firm's financial condition worsens.

Importantly, efficiency gains are made by changing input or output quantities in ways that reduce costs, increase revenues, and/or reduce risks to increase value for a given set of prices. This is in contrast to market power gains discussed in Section 4, in which value is created by institutions changing prices to their advantage.

Static efficiency analyses evaluate scale, scope, and product mix efficiencies of financial institutions without regard to how they achieved their current output points. The dynamic analyses examine changes in efficiency after M\&As or compare the efficiency of recently consolidated institutions with other institutions, incorporating any changes in X-efficiency as well as scale, scope, and product mix efficiencies. 


\subsection{Static efficiency analyses - Scale, scope, and product mix efficiencies}

\subsubsection{Cost scale, scope, and product mix efficiencies studies}

Research on financial institution scale efficiencies in the late 1980s and early 1990s usually used data on U.S. banks from the 1980s, and specified multiple banking products. These studies generally used costs and not revenues, and usually specified a translog functional form, which imposes a U-shape (in logs) on the multiproduct ray average cost curve. The consensus finding was that the average cost curve had a relatively flat U-shape with medium-sized banks being slightly more scale efficient than either large or small banks. Only small banks had the potential for economically significant scale efficiency gains and the measured inefficiencies were usually relatively small, on the order of $5 \%$ of costs or less. The location of the scaleefficient point — the bottom of the average cost $\mathrm{U}$ - differed among studies, but was usually between about $\$ 100$ million and $\$ 10$ billion in assets, with a larger scale efficient point generally being found when the banks in the sample were larger (Hunter and Timme 1986, Berger, Hanweck, and Humphrey 1987, Ferrier and Lovell 1990, Hunter, Timme, and Yang 1990, Noulas, Ray, and Miller 1990, Berger and Humphrey 1991, Mester 1992b, Bauer, Berger, and Humphrey 1993, Clark 1996).

Despite the different findings, almost all of the studies suggested that there were no significant scale efficiencies to be gained and possibly some slight scale efficiency losses to be suffered from M\&As involving large banks. ${ }^{16}$ Similarly, studies of cost scale efficiency in the insurance industry typically found most firms to be below efficient scale, but found the largest firms to be above efficient scale (Grace and Timme 1992, Yuengert 1993, Gardner and Grace 1993, Cummins and Zi 1998). In the securities industry, small specialized firms appeared to exhibit economies of scale, while large, diversified firms exhibited scale

\footnotetext{
${ }^{16}$ Some research also suggests very little potential for scale efficiency gains at the bank branch office level through in-market M\&As by closing offices and transferring the deposits and loans to nearby offices. Although offices may be considerably smaller than the scale efficient point, the estimated potential savings in cost scale efficiency are relatively small - about $3 \%$ of total branching costs in one study - because the average cost curve for branches appears to be quite shallow (Berger, Leusner, and Mingo 1997). Moreover, anything near these potential gains is unlikely to be achieved because the branches of the consolidating institutions need to be near each other, and this is relatively rare. Only $6.8 \%$ of urban U.S. banking offices in 1985 and only $3.3 \%$ of rural banking offices were acquired over the next 10 years by banking organizations with offices in the same ZIP code (Avery, Bostic, Calem, and Canner 1999). Moreover, there is often a run-off of deposits and assets when branch offices are closed due to the loss of convenience and other factors (Savage 1991).
} 
diseconomies (Goldberg, Hanweck, Keenan, and Young 1991).

Research on financial institution cost scope and product mix efficiencies often came out of the same research studies and used the same cost functions as the scale efficiencies. Scope efficiencies were measured by comparing the predicted costs of an institution producing multiple financial services and a set of institutions that each specialize in producing a subset of these services. Scope efficiencies are often difficult to estimate because there are usually no specializing firms in the data sample, creating extrapolation problems. ${ }^{17}$ Studies of product mix efficiencies often reduce these problems by evaluating somewhat different output points, such as points near zero outputs, or by using concepts such as expansion-path subadditivity which combine scale and product mix efficiencies. The empirical results and implications for consolidation of scope and product mix efficiency studies were qualitatively similar to those for the scale efficiency studies - very few cost savings were implied from consolidating the outputs of different banks (Berger, Hanweck, and Humphrey 1987, Hunter, Timme, and Yang 1990, Pulley and Humphrey 1993, Noulas, Miller, and Ray 1993, Ferrier, Grosskopf, Hayes, and Yaisawarng 1993).

\subsubsection{Recent innovations in scale, scope, and product mix research}

Despite this early research, some recent research using different econometric techniques, different efficiency concepts, and/or more recent data from the 1990s suggests that there may be more substantial scale, scope, and product mix efficiency gains available from consolidation. A recent analysis found the 1990s data displayed substantial cost scale economies, on the order of about $20 \%$ of costs, for bank sizes up to about $\$ 10$ billion to $\$ 25$ billion in assets (Berger and Mester 1997). The data on larger banks were too thin to draw firm conclusions, but the prospects for cost scale efficiency savings or at least little or no losses from M\&As among large banks appears to be greater in the 1990s than in the 1980s. This change may in part reflect technological progress that increased scale economies in producing financial services as described in Section 3 above. The change in scale efficiency may also partially reflect regulatory changes such as the elimination of geographic restrictions on bank branching and BHC expansion, which may make it less costly

\footnotetext{
${ }^{17}$ The problems of extrapolation, often combined with the problems of the translog specification and the problem of measuring scope efficiencies away from the best-practice efficient frontier (where scope efficiencies are defined), can yield measured scope efficiency estimates that are erratic and beyond credible levels (Berger and Humphrey 1991, Pulley and Humphrey 1993, Mester 1993).
} 
to increase scale. Finally, the data suggest that part of the change in scale efficiency reflects the lower openmarket interest rates of the 1990 s, given that a greater proportion of large banks' liabilities tend to be sensitive to open-market rates (Berger and Mester 1997).

Recent studies have also examined the effects of bank scale, scope, and product mix on revenue and profit efficiency. The scale results are ambiguous, with some evidence of mild ray scale efficiencies in terms of joint consumption benefit for customers (Berger, Humphrey, and Pulley 1996), and profit efficiency sometimes being highest for large banks (Berger, Hancock, and Humphrey 1993), sometimes being highest for small banks (Berger and Mester 1997), and sometimes about equal for large and small banks (Clark and Siems 1997). In terms of scope and product mix economies, one study found little or no revenue scope efficiency between deposits and loans in terms of charging customers for joint consumption benefits (Berger, Humphrey, and Pulley 1996) and another study of profit scope economies found that joint production is optimal for most banks, but that specialization is optimal for others (Berger, Hancock, and Humphrey 1993).

As noted above, we also include improvements in the risk-expected return tradeoff from improvements in risk diversification as potential efficiency gains from consolidation. Some studies have found that bank managers act in a risk-averse fashion, trading off between risk and expected return, and therefore may tolerate additional costs expended to keep risk under control (Hughes, Lang, Mester, and Moon 1996,1997, Hughes and Mester 1998). Taking risk into account adds the potential for scale, scope, and product mix efficiencies in managing risk. A greater scale, a more diverse mix of financial services provided, or an increased geographical spread of risks usually implies the potential for improved diversification, so the same protection against financial distress can be attained with fewer resources. For example, one early study found scale efficiency from diversification of loan risk - as bank loan portfolios increased in size up to about $\$ 1$ billion, the standard deviation of the rate of return on loans fell precipitously, presumably because of diversification benefits (McAllister and McManus 1993). This does not necessarily mean that large banks choose lower levels of overall risk, as they may choose to take on risk elsewhere in their portfolios to achieve a higher expected rate of return.

Several studies found that higher ratios of equity capital are associated with greater resources devoted to managing risks, and that these resource costs were lower for the largest U.S. banking 
organizations, consistent with scale efficiency (Hughes, Lang, Mester, and Moon 1996,1997, Hughes and Mester 1998). Another study found that large banking organizations are better diversified but no less risky than small institutions - large organizations take the benefits of an improved risk-expected return tradeoff primarily in higher expected returns by increasing their holdings of risky loans and reducing their equity ratios (Demsetz and Strahan 1997).

Finally, one study looked directly at the diversification gains from improvements in the risk-expected return tradeoff by examining the tradeoffs among expected profit, variability of profit, profit inefficiency, and insolvency risk for large U.S. banking organizations in the early 1990s (Hughes, Lang, Mester, and Moon 1999). They found that when organizations are larger in a way that geographically diversifies, especially via interstate banking that diversifies macroeconomic risk, efficiency tends to be higher and insolvency risk tends to be lower. However, greater scale and greater numbers of branches without geographic diversity was associated with lower insolvency risk but no difference in efficiency. Thus, scale alone, holding the scope of operations constant, did not necessarily improve performance. Rather, gains came primarily from operating in multiple states, especially when this diversified macroeconomic risk. Similarly, one of the other studies found efficiency increased with the number of states of operation, confirming the benefits from geographical expansion (Hughes, Lang, Mester, and Moon 1996).

\subsubsection{Scale, scope, and product mix efficiency effects of combining banks with nonbanks}

There is some research on the efficiency effects of combining commercial banks with other types of financial service firms. A study of cost scope efficiency of German universal banks found mostly diseconomies of producing loans and investment-oriented services within the same institution (Lang and Welzel 1998). Some studies evaluated the risk-reducing potential of combining banking and nontraditional activities using U.S. data. Simulation-type studies combined the rates of return earned by banking organizations and other financial institutions from the 1970s and 1980s (Kwast 1989, Rosen, Lloyd-Davies, Kwast, and Humphrey 1989, Boyd, Graham, and Hewitt 1993). The results were mixed, with some combinations yielding reductions in predicted failure probability and other predicting increased probability of failure. Another study of U.S. firms also found that risk could be reduced by combining banks with nonbank financial companies, particularly insurance firms (Saunders and Walter 1994). In addition, 
combining banking and insurance has been found to have increased competition and diversification in the U.K. (Llewellyn 1995). A recent study of interindustry experience in the U.S. in the 1990s found that securities subsidiaries provide BHCs with potential diversification benefits because of low correlations of returns with the rest of the BHC (Kwan 1997).

Some recent research has identified other efficiency benefits and costs of combining banking with other activities. Allowing combinations of banks and other firms, particularly nonfinancial firms, may foster a more effective market for corporate control in banking, in part through hostile takeovers (Prowse 1997). Permitting banks to have substantial ownership stakes in nonfinancial firms may also mitigate information problems that arise when ownership is diffuse or coordination problems associated with the conflicting interests of diverse stakeholders (Hoshi, Kashyap, and Sharfstein 1991). Alternatively, the inclusion of underwriting and lending in the same institution may also lead to conflicts of interest, such as might occur if an institution underwrites additional equity or debt issues to help salvage its own problem loans, although most studies of universal banks suggest that investors understand these conflicts (Ang and Richardson 1994, Kroszner and Rajan 1994,1997, Puri 1996, Gande, Puri, and Saunders 1998). It has also been argued that there may be less financial innovation in a universal banking system because the incentive to produce innovative financial solutions to attract corporate customers to commercial banks from investment banks or vice versa would be reduced if the same institution provided both types of services (Boot and Thakor 1996). In addition, German-style universal bank-dominated financial systems may offer better intertemporal risk-sharing at the cost of less cross-sectional risk taking than U.S.-style market-based financial systems with commercial banks (Allen and Gale 1997). ${ }^{18}$

\subsection{Dynamic efficiency analyses - Changes in efficiency associated with M\&As}

The dynamic studies of changes in efficiency associated with M\&As take into account changes in X-efficiency - how much closer to or further from the optimal point on the best-practice efficient frontier these firms have moved - in addition to changes in scale, scope, and product mix efficiency. These studies use the cost frontier, the profit frontier, or the risk-expected return frontier. Ex ante, there is great potential

\footnotetext{
${ }^{18}$ For a recent review of commercial banks in the securities industry, see Santos (1998).
} 
for X-efficiency improvement from financial institution M\&As, X-inefficiencies on the order of $20 \%$ or more of total industry costs, and about half of the industry's potential profits have been found. ${ }^{19}$

\subsubsection{Cost X-efficiency studies of banks}

There are a number of studies of the effects of M\&As on bank cost X-efficiency. These studies employed cost functions to control for input prices, product mix, and other factors. These studies are superior to the cost ratio studies discussed in Section 4 in that by controlling for prices, they are able to disentangle efficiency changes from changes in market power which may be incorporated into prices. The cost function studies also take into account the different costs of different product mixes. Despite the differences in methodology from the cost ratio studies, the results of the cost X-efficiency studies were quite similar. The studies of U.S. banking generally show very little or no cost X-efficiency improvement on average from the M\&As of the 1980s, on the order of $5 \%$ of costs or less (Berger and Humphrey 1992, Rhoades 1993, DeYoung 1997, Peristiani 1997). If there were technological gains on average from consolidating branches, computer operations, payments processing, etc., these may have been offset by managerial difficulties in monitoring the larger organizations, conflicts in corporate culture, or problems in integrating systems. ${ }^{20}$

The cost efficiency studies using data from the early 1990s are mixed. One set of studies of M\&As of large U.S. institutions, most of which were in-market M\&As, found modest cost X-efficiency gains in most cases (Rhoades 1998). Another study found very little improvement in average cost X-efficiency for M\&As of either large or small banks (Berger 1998). Some recent case studies suggest that the cost efficiency effects of M\&As may depend on the type of M\&A, the motivations behind it, and the manner in which the management implemented its plans (Frei, Harker, and Hunter 1995, Frei and Harker 1996, Calomiris and Karceski 1998, Rhoades 1998).

\footnotetext{
${ }^{19} \mathrm{We}$ review here only the X-efficiency effects of M\&As. For a general review of X-efficiency studies of financial institutions, see Berger and Humphrey (1997), and for a recent survey of insurance industry studies, see Cummins and Weiss (1999).

${ }^{20}$ The findings of little improvement in either cost ratios or cost X-efficiency do not necessarily conflict with the findings of large cost savings on the order of $30 \%$ or more of the operating expenses of the target often made in consultant studies. These differences can be explained primarily by differences in the way in which the cost savings are stated. See Berger and Humphrey (1992) for a detailed discussion.
} 


\subsubsection{Profit efficiency studies of banks}

The profit efficiency effect of M\&As is the most inclusive. It embodies the scale, scope, product mix and X-efficiency effects for both costs and revenues and also includes at least some of the diversification effects. Two studies of the profit efficiency effects of U.S. bank M\&As from the 1980s and early 1990s found that M\&As improved profit efficiency, and that this improvement could be linked to improved diversification of risks(Akhavein, Berger, and Humphrey 1997, Berger 1998). After consolidation, the banks tended to shift their asset portfolios from securities to loans, have more assets and loans per dollar of equity, and to raise additional uninsured purchased funds at reduced rates, consistent with a more diversified loan portfolio. In effect, capital market participants gave consolidated banks "credit" for diversification by allowing them to increase their lending without penalty of more equity or higher rates on uninsured funds. One study used a Tornqvist productivity index, a value-weighted output index divided by a value-weighted input index, which is similar to profit efficiency and obtained consistent findings (Fixler and Zieschang 1993). The study of the diversification gains discussed above (Hughes, Lang, Mester, and Moon 1999) also conducted a dynamic analysis by evaluating how their measures differed for organizations that were recent acquirers versus those that were not recent acquirers. The diversification benefits were still present, but were weaker for the recent acquirers. ${ }^{21}$

\subsubsection{Dynamic efficiency studies of nonbanks}

The few dynamic efficiency studies of the consolidation of other financial service firms are generally consistent with the dynamic bank M\&A studies. A study of life insurance M\&As in the early 1990s found improved cost and revenue efficiency for acquired firms (Cummins, Tennyson, and Weiss 1999). Credit unions are not-for-profit organizations, so their efficiency must be estimated differently. In place of maximizing profits, they are modeled as optimizing the quantities, prices, and variety of services provided to members, while minimizing operating expenses. One study of credit union M\&As found that service provision per dollar of operating expense improved for members of acquired credit unions, but was

\footnotetext{
${ }^{21}$ See Pilloff and Santomero (1998) for additional review of the bank M\&A efficiency literature, see Calomiris (1999) for criticisms of this approach, and see Morgan (1998) for additional review of the diversification benefits of consolidation.
} 
unchanged in acquiring unions (Fried, Lovell, and Yaisawarng 1999).

\subsubsection{Ex ante conditions that predict efficiency improvements from M\&As}

Some of the dynamic studies also examined the extent to which the efficiency consequences of individual M\&As could be predicted ex ante. If ex ante conditions that make a specific M\&A very likely or unlikely to improve efficiency can be identified, this may provide valuable information to help policy makers trade off between expected efficiency changes and other expected consequences in the M\&A approval/denial process.

Some studies measured whether "mergers of equals," in-market M\&As, or those in which the acquiring institution was much more efficient than the acquired institution were helpful in predicting efficiency changes from consolidation. The results were mixed, with some studies finding these factors to predict future efficiency improvement and others finding that these factors were not significant predictors. Two of the studies found that substantial efficiency gains were predicted if either or both of the participating banks were less efficient than their peers prior to consolidation, and this result held for cost and profit efficiency, and for M\&As involving large or small banking organizations (Akhavein, Berger, and Humphrey 1997, Berger 1998). These findings suggest that the M\&A event itself may have"woken up" management to the need for improvement or may be used as an excuse to implement substantial unpleasant restructuring ("rightsizing") needed to improve efficiency that might otherwise create substantial morale problems.

\subsubsection{Studies of the external effect}

Some studies have examined the external effect of consolidation on the efficiency of other institutions in the market. One study found that out-of-state entry is associated with reduced cost efficiency in the short term, but increased cost efficiency in the long term (DeYoung, Hasan, Kirchhoff 1998). One common external response to M\&As is de novo entry. One study found that de novo banks begin less efficient than mature banks of similar size, make up most of the difference within three years, and become equally efficient by about age nine (DeYoung and Hasan 1998).

\subsubsection{Efficiency effects of international M\&As and non-U.S. M\&As}

The research on the efficiency effects of international M\&As and M\&As outside the U.S. suggest that there may be some important differences of these consolidations from those among domestic U.S. 
institutions. A study of domestic and international M\&As of credit institutions in Europe found that some groups of M\&As, particularly international consolidations, tended to improve cost efficiency, whereas other types tended to decrease cost efficiency (Vander Vennet 1996,1997). A study using Italian data also found that most M\&As improved cost X-efficiency (Resti 1998). Another study of U.K. building societies found significant efficiency gains following acquisitions (Haynes and Thompson 1997).

Other studies compared the efficiencies of foreign-owned versus domestically-owned institutions within a single country. Several studies found that foreign-owned banks in the U.S. were significantly less cost efficient than domestically-owned banks (Hasan and Hunter 1996, Mahajan, Rangan, and Zardkoohi 1996, Chang, Hasan, and Hunter 1998). ${ }^{22}$ Consistent with this finding, one study found lower profit efficiency for foreign-owned banks and attributed this to excessive reliance on purchased funds (DeYoung and Nolle 1996). The foreign-owned banks may have in effect traded current profits for rapid expansion of market share, given that purchased funds are more expensive but may be raised more quickly than core deposits. One study proposed the alternative theory that foreign banks tend to acquire domestic banks that already have performance problems, and the data are also consistent with this theory (Peek, Rosengren, and Kasirye 1999). This study also found that changes in business strategy for the foreign owners were generally not successful in raising the acquired banks' performance to the levels of their domestic peers.

\subsection{Caveat about measuring efficiency effects of consolidation}

As a caveat, we note that the efficiency measures do not incorporate any benefits or costs of changes in efficiency that may be passed through to customers through changes in prices or quality of service because of competitive pressures. For example, an improvement in bank productivity that is partially passed on to depositors through higher interest rates paid or increased convenience will not fully appear in measured efficiency. This is because prices are taken as given and service quality is difficult to control for when measuring efficiency.

\section{Research on the consequences of consolidation for the availability of services to small customers}

\subsection{Background on consolidation and service availability}

\footnotetext{
${ }^{22}$ In contrast, one study of Indian banks found government-owned banks to be most efficient, followed by foreign-owned banks, followed by private domestic banks (Bhattacharya, Lovell, and Sahay 1997).
} 
A reduction in the availability of services to small customers is not a direct motivation for consolidation, but may occur indirectly as a result of other motives. As discussed above, some in-market M\&As may increase market power, resulting in less favorable prices for retail depositors and small business borrowers, which may reduce the number of small customers who avail themselves of these services. Consolidated institutions may also exercise additional market power by directly reducing the availability of these services (e.g., closing branch offices).

Improvements in efficiency associated with consolidation may also reduce the availability of services to some small customers. As discussed above, M\&As may help resolve control problems with managers who made non-value maximizing choices, possibly including unprofitable branch offices or small business loans. It is also possible that more efficient managers will increase the supply of services to small customers because the more efficient institutions are able to serve more customers profitably.

The increases in size and/or organizational complexity associated with M\&As may also create opportunities to improve efficiency by changing focus away from or toward serving small customers. The large institutions created by consolidation may shift away from providing retail-oriented services for small depositors and borrowers because of new opportunities to provide wholesale services for large capital market participants. Small institutions generally cannot make large business loans, underwrite new securities issues, or provide the full array of risk-management services because of insufficient scale of operations, lack of diversification, legal lending limits, etc.

The larger institutions created by consolidation may also choose to provide fewer retail services to small customers because of Williamson $(1967,1988)$ type organizational diseconomies of providing these services along with providing wholesale capital market services to large customers. That is, it may be scope inefficient for one institution to produce outputs which may require implementation of quite different policies and procedures. These diseconomies may be most likely to arise in providing services to informationally opaque small businesses for whom intimate knowledge of the small business, its owner, and its local market gained over time through a relationship with the financial institution is important. Large institutions may be inefficient at providing these relationship-based services along with the transactions-based services 
provided to large, relatively informationally transparent customers. ${ }^{23}$

A financial institution's organizational complexity may also make it costly to provide locally-based services to small customers. For example, a multibank BHC with multiple layers of management that acquires an independent bank in another region or another country may find it costly to process relationshipbased information acquired through contact over time by a local loan officer in a distant market.

Importantly, these arguments do not suggest that the large, complex financial institutions created by consolidation would reduce services to all small customers, rather just to those customers who rely on relationships. Small customers with strong financial statements and valuable collateral may receive essentially the same transactions-based services as large customers, and could see an increase in available services from their consolidated institutions, such as underwriting or risk management services.

An alternative theory may suggest improved availability of services to small customers from consolidation, especially during times of financial stress. Large, organizationally complex, diversified financial institutions may be better able to withstand financial crises and continue to provide services. In contrast, small, unaffiliated, undiversified institutions may more often have to withdraw credit and other service from small customers in times of financial stress. Moreover, even in periods without financial stress, the large, organizationally complex institutions created by consolidation may act as efficient internal capital markets that can allocate financial resources where and when they are most needed. ${ }^{24}$

\footnotetext{
${ }^{23}$ The empirical research on relationships between banks and small businesses generally supports the notions that banks use these relationships to garner information and that small businesses benefit from these relationships. The research using U.S. data generally found that small businesses with stronger banking relationships received loans with lower rates and fewer collateral requirements, had less dependence on trade credit, enjoyed greater credit availability, and protection against the interest rate cycle than other small businesses (Petersen and Rajan 1994,1995, Berger and Udell 1995, Blackwell and Winters 1997, Berlin and Mester 1998, Cole 1998, Hubbard, Kuttner, Palia 1998). The U.S. data also suggest that banks gather valuable private information from depositors and in some cases use this information in credit decisions (Allen, Saunders, and Udell 1991, Nakamura 1993, Frieder and Sherrill 1997, Mester, Nakamura, and Renault 1998). The evidence using European and Asian banking data also usually shows support for the value added of relationships, although some of the European evidence suggests exceptions (Hoshi, Kashyap, and Sharfstein 1990, Ongena and Smith 1997, Elsas and Krahnen 1997, Harhoff and Korting 1997, Angelini, Di Salvo, and Ferri 1998). For a general review of small business finance, see Berger and Udell (1998).

${ }^{24}$ Other changes in organizational focus/managerial behavior associated with consolidation may also alter the availability of services to small customers. For example, the consolidated institution may change the policies and procedures of the acquired part of the institution to bring them into accord with the acquirer's
} 
The total effect of consolidation on the availability of financial services to small customers also depends upon the external effect of consolidation on the supply of these services by other institutions in the same local markets. For example, if institutions participating in M\&As reduce the availability of small business services, other financial service firms may pick up these customers if it is value-maximizing for them to do so.

These theories have been tested using both static and dynamic methods. The static analyses tested the effects of financial institution size and organizational complexity on the supply of services to small customers, but did not distinguish institutions that had recently engaged in M\&As from other institutions. The dynamic analyses compared the availability of these services before and after M\&As or between institutions that have recently engaged in M\&As and those that have not.

\subsection{Static analyses of service availability - Effects of institution size and organizational complexity}

Static analyses have shown that large banking organizations devote lesser proportions of their assets to small business loans than do small organizations (Berger, Kashyap, and Scalise 1995, Keeton 1995, Levonian and Soller 1995, Berger and Udell 1996, Peek and Rosengren 1996, Strahan and Weston 1996, Cole, Goldberg, and White 1997). As of the mid-1990s, U.S. banks with less than $\$ 100$ million in assets invested about $9 \%$ of their assets in domestic small business loans (loans to business borrowers with bank credit less than $\$ 1$ million), as opposed to only about $2 \%$ of assets for banks with over $\$ 10$ billion in assets. ${ }^{25}$

This finding does not, however, necessarily imply that small businesses can only receive significant amounts of bank credit in markets with a preponderance of small banks. One study found that in the long run, the probability that a small firm obtains a line of credit or pays late on its trade credit does not depend in an important way on the presence of small banks in the market (Jayaratne and Wolken 1999). These results are consistent with the possibility that the number of small banks in the market may endogenously arise as a function of the demands of the local small businesses. These results are also consistent with the

pre-M\&A focus on either small or large customers.

${ }^{25}$ Very little research has been published regarding the effects of consolidation on specific types of business or consumer loans. One exception is a study that found that U.S. banks and savings and loans with over $\$ 1$ billion in assets provided about $81 \%$ of the dollars of community development lending in 1996, close to proportionate with their percentage of assets controlled (Bostic and Canner 1998). 
finding of a strong positive external effect of consolidation on the lending of other banks in the same local market discussed below.

The effects of organizational complexity - measured by additional layers of management, operation in multiple states, being in more financial lines of business, etc. - are ambiguous. Studies that examined a number of dimensions of complexity found that some dimensions were empirically associated with more small business lending and others were empirically associated with less of this lending (Berger and Udell 1996, Berger, Saunders, Scalise, and Udell 1998). One study found a negative effect of multibank BHC affiliation (DeYoung, Goldberg, and White 1999), and two studies split on the direction of the effect of outof-state ownership of banks (Keeton 1995, Whalen 1995).

The Williamson $(1967,1988)$ organizational diseconomies theory discussed above predicts that it will be relationship-based small business lending that will be relatively unavailable from large, complex organizations, rather than small business loans as whole. Two studies provide evidence consistent with this prediction. One study found that large banks tend to charge about 100 basis points less on small businesses loans and require collateral about $25 \%$ less often than small banks, other things equal (Berger and Udell 1996). These data are consistent with the view that large banks tend to issue small business loans to higherquality transactions-based credits, rather than relationship-based loans that tend to have higher interest rates and collateral requirements. Another study found that large banks tend to base their small business loan approval decisions more on financial ratios, whereas the existence of a prior relationship with the borrowing firm mattered more to decisions by small banks (Cole, Goldberg, and White 1997).

As noted above, the large, organizationally complex, diversified institutions created by consolidation may provide a better buffer against financial institution stress or may be more efficient at allocating scarce financial capital than small, unaffiliated, undiversified institutions. Consistent with these arguments, one study found that during the U.S. credit crunch of the early 1990 s, a $\$ 1$ decline in equity capital at a small bank reduced business lending more than a $\$ 1$ decline at a large bank (Hancock and Wilcox 1998). Moreover, this study found that the financial distress of small financial institutions adversely affected the health of small businesses in the same state, reducing employment, payroll, and number of small businesses in the state. Other studies found that BHCs serve as internal capital markets or sources of strength for 
funding loans. Loan growth by banks in multibank BHCs was less constrained by the banks' own financial conditions than the financial condition of their BHC (Houston, James, and Marcus 1997, Houston and James 1998). ${ }^{26}$

\subsection{Dynamic analyses of service availability}

\subsubsection{Effects of M\&As on small business lending}

A number of dynamic studies examined the effects of U.S. bank M\&As on small business lending (Keeton 1996,1997, Peek and Rosengren 1996,1998, Strahan and Weston 1996,1998, Craig and Santos 1997, Kolari and Zardkoohi 1997a,b, Zardkoohi and Kolari 1997, Walraven 1997, Berger, Saunders, Scalise, and Udell 1998). The measured effects of consolidation on lending by the participating institutions appear to depend on the type of M\&A, the sizes of the institutions, the econometric technique employed, and the number of years of data used after the consolidation date. The most common findings are that consolidations of large banking organizations tend to reduce small business lending, whereas consolidations involving small organizations tend to increase small business lending, although there are exceptions. Given that large-bank M\&As account for most of the assets involved in M\&As, the overall effect on small business lending by consolidating institutions is generally negative. One study examined the probability that small business loan applications will be denied by consolidating banks and other banks in their local markets and found no clear positive or negative effects (Cole and Walraven 1998). One study of Italian banks found that M\&As tended to reduce lending to small businesses by the consolidated institution, with larger reductions when larger banks were involved (Sapienza 1998).

One of these studies measured the external effect of M\&As on the lending of other banks in the same local markets and found that changes in the supplies of small business credit by these other banks tended to offset much, if not all of the negative effects of M\&A participants (Berger, Saunders, Scalise, and Udell 1998). Part of the external effect may be from de novo entry. Several studies found that de novo banks tend

${ }^{26}$ Diversification of markets, as well as diversification of financial institutions, can help spread risks. Studies found that the nationwide consolidation of U.S. securities markets significantly diversified income risks across individual states, whereas the smaller scale and fragmented structure of European securities markets provided much less diversification of income risks across individual nations (Asdrubali, Sørensen, and Yosha 1996, Sørensen and Yosha 1997). 
to lend more to small businesses as a percentage of assets than other small banks of comparable size and that this high percentage lasts for a number of years, consistent with a positive external effect of M\&As on small business lending (Goldberg and White 1998, DeYoung 1998, DeYoung, Goldberg, and White 1999).

\subsubsection{Effects of M\&As on branch office availability}

There has been limited study of the effects of consolidation on bank branch offices, which provide much of the deposit and loan services to small consumers and small businesses. One dynamic study of the effects of M\&As on the number of bank branches in local markets in the U.S. incorporated both the actions of the M\&A participants and the external effects on other banks in the same markets (Avery, Bostic, Calem, and Canner 1999). They found that M\&As of banks with branches in the same ZIP codes reduced the number of branches per capita, but that other M\&As had little effect on branch office availability. Given that ZIP codes are fairly small geographic areas, the within-ZIP branch office closings may not substantially reduce the convenience or availability of services to the affected small customers.

\subsection{Caveat regarding the future effects of consolidation on small customers}

We caution about extrapolating the results on the availability of services to small customers to the future. There are very few studies of the external effects of consolidation on these customers, and very little research outside of U.S. banking. It is also possible that technological change may alter the effects of institution size and complexity on the supply of these services. Technological improvements such as credit scoring and securitization may diminish the importance of relationships to small businesses. Similarly, improved technology and marketing that changes the delivery of financial services to small customers may make traditional branch offices less important in the future. In addition, heightened legislative, regulatory, and public concern over service to small customers may make it difficult for consolidating institutions to reduce the supplies of these services.

\section{Systemic consequences of consolidation}

The consequences of consolidation discussed thus far affect primarily individual firms and local markets. In this section, we discuss additional potential consequences of consolidation with systemwide ramifications - effects on the payments system and on the safety and soundness of the financial system.

\subsection{Consolidation and payments system efficiency}




\subsubsection{Background on consolidation and payments system efficiency}

Consolidation can have several effects on the efficiency of the payments system. ${ }^{27} \mathrm{M} \&$ As reduce the amount of payments processing because payments between consolidating institutions become "on-us" items. Payments between these institutions or between their customers require no interbank transfer of funds, as the transaction is internal to the consolidated institution. ${ }^{28}$ In addition, many of the remaining interbank payments may be cleared more quickly and efficiently because there are fewer endpoints to which to send payment information or payment instruments. Thus, even if individual institutions become no more proficient at handling check, credit card, debit card, automated clearinghouse (ACH), or wire payments, payments system efficiency may increase with consolidation as the number of institutions declines.

Financial service industry consolidation might also improve efficiency by allowing resources to flow to more efficient payments processors or by allowing banks to find more efficient means to exchange payments. Consolidation in the U.S. or in Europe may allow some large institutions to form more efficient payments networks that are not possible with the current fragmented industry structure. A simulation of nationwide banking in the U.S. suggested substantial increases in market share for such banks and a reduction in payments services provided by the Federal Reserve (Berger and Humphrey 1988).

In addition, consolidation may speed adoption of electronic payments in place of paper checks and other costly payment instruments. The benefits to consumers of electronic payment methods often depend upon having easy access to the same technology in many locations, which may require coordination across many payment sites controlled by different producers. Consolidation of the financial services industry into fewer and larger players may make it easier to agree on payments standards and a common technology with standardized protocols and fixed technical standards to take advantage of network economies. Alternatively, the necessary cooperation may be achieved without substantial financial services industry consolidation through the use of the correspondent banking system, outsourcing to nonbank service providers, common

\footnotetext{
${ }^{27}$ For recent reviews of payments system research, see Berger, Hancock, and Marquardt (1996) and Hancock and Humphrey (1998).

${ }^{28}$ The elimination of some of the interbank transfers depends upon the banks being merged into a single bank, rather than becoming affiliates within a BHC. Banks in the same BHC must keep separate books and transfer funds when the customer of one bank pays a customer of the other bank.
} 
ownership of network facilities, government mandate of technical standards, or mandatory sharing rules (Solomon 1999). One study found that nations with more consolidated banking systems had greater use of electronic payments systems, and attributed this to the greater ease in agreeing on standards, technology, and the use of centralized account information (Humphrey, Pulley, and Vesala 1996).

Similarly, consolidation may improve scale efficiency in back-office payments operations. Larger processing sites may yield scale efficiencies in processing payments information and instruments. However, this may also raise the telecommunications and/or transportation costs in sending the electronic information or paper to the more centralized processing sites. As with the network economies, exploitation of scale economies in back-office payments processing does not necessarily require that the banks consolidate — the consolidated processing sites may be owned by existing financial institutions and the services sold to other institutions, or may be outsourced to nonbanks that specialize in payments processing (e.g., private-sector service bureaus, Federal Reserve offices).

In addition, there may be a "market failure" in payments pricing in which payors do not bear the full marginal costs of their payments and receive float benefits during the time it takes to collect the funds. For example, U.S. payor banks and their customers do not pay for the full collection costs of check payments, and they benefit from collection float, resulting in additional real resources being spent in the payment and collection processes. This may also lead to the overuse of paper instruments, although it is not agreed whether this distortion is large (Johnson 1968, Humphrey and Berger 1990, Wells 1996). Consolidation may remove some of these distortions by making the payor and collecting bank more often be the same institution and by reducing the number of institutions involved in negotiating agreements to move to more efficient collection procedures. ${ }^{29}$ Consolidation could result in more rational pricing of payments, agreements to remove much of the float benefits of checks (as has occurred in the highly concentrated Canadian and Norwegian banking industries), as well as speeding the adoption of electronic technologies (Humphrey and Berger 1990, Hancock and Humphrey 1998, Humphrey, Pulley, and Vesala 1998).

\footnotetext{
${ }^{29}$ For example, the large banks in the New York Clearing House Association, in conjunction with other large U.S. banks, are now attempting to set up a nationwide, electronic presentment arrangement for checks and ACH (Humphrey, Pulley, and Vesala 1998).
} 


\subsubsection{Static analyses of scale efficiency in payments processing}

Static analyses of the cost efficiency of payments operations may help predict some of the efficiency consequences of consolidation. These studies use data on Federal Reserve payments processing costs, rather than private-sector costs because data availability. Nonetheless, the results of these analyses may generalize. The Federal Reserve has access to essentially the same technology as private-sector payments processors. In addition, under the Depository Institutions Deregulation and Monetary Control Act of 1980 (DIDMCA), the Federal Reserve's incentives to keep costs under control are similar to the incentives of other processors because the Federal Reserve must set prices to recover its costs (including imputed costs that other processors must bear, such as taxes, interest on debt, deposit insurance premiums, etc.).

Early research on scale efficiency in check processing found that many checks were processed at Federal Reserve offices with significant diseconomies of scale during the 1970 s, i.e., the offices were on the upward sloping part of the average cost curve above the efficient scale point. These scale inefficiencies were mostly eliminated in the early 1980s, in part because of the pricing and competition brought about by DIDMCA (Humphrey 1982). A later study that accounted for X-efficiency and technological progress found similar scale efficiency results, but found little evidence of improvements in X-efficiency or technological progress after DIDMCA (Bauer and Hancock 1993). This type of analysis was also applied to ACH operations, with the finding of very substantial reductions in costs over time, largely due to technological improvements in computing and communications technologies and the exploitation of scale economies

(Bauer and Hancock 1995). One study examined check, ACH, and Fedwire processing in the first half of the 1990s and found substantial technological progress over time and significant scale economies for both electronic payments methods, ACH and Fedwire (Bauer and Ferrier 1996). Check processing showed little measurable progress over time, but this may be due in part to a measurement problem, given that many of the most easy-to-process items such as payroll checks switched to ACH.

\subsubsection{Dynamic analysis of consolidation and payments processing efficiency}

One dynamic study examined the effects of consolidating Fedwire processing into one main site with two back-up sites from the original 36 sites in the late 1970s (Hancock, Humphrey, and Wilcox 1999). This study took into account scale economies, the falling cost of computer and telecommunications technologies, 
and the transition costs of leaving some sites temporarily idle as consolidation proceeded. They found substantial scale economies in Fedwire operations and an improvement in cost efficiency of Fedwire from consolidation in the long run, although there were significant transition costs. Again, it seems likely that to some degree, these results may carry over to consolidation of private-sector processors.

An important caveat is that even if consolidation of payments processors improves efficiency, this does not imply that a large amount of financial institution consolidation needs to occur to achieve most of the gains. As discussed above, it is possible for institutions to share some of these benefits of a consolidated payments processor through a correspondent banking system, outsourcing to specialists, etc.

\subsection{Financial system safety and soundness considerations}

\subsubsection{Consolidation, systemic risk, and safety net subsidies}

Systemic risk is defined here as the risk that credit or liquidity problems of one or more financial market participants creates substantial credit or liquidity problems for participants elsewhere in the financial system. The contagion effects can be transferred through the financial system in a number of ways, including failures to settle in payments system, panic runs following revelation of an institution's problems because of a lack of transparency, or falling prices, liquidity problems, or markets failing to clear when large volumes of securities are offered for sale simultaneously.

Consolidation may affect systemic risk in part because it changes the risks of individual institutions, particularly the risks of large institutions whose credit or liquidity problems may affect many other institutions. If the risk of an individual institution is higher, this raises the probability that the institution will fail or become illiquid before settling some of its payments obligations, exposing other institutions directly to risks as payees, or indirectly through contributing to panic runs or securities markets problems. As discussed above, M\&As may either increase or decrease the risk of institutions, largely depending upon whether any diversification gains are offset by the institutions' pursuit of additional risks. The research results suggested that in many cases, consolidating institutions chose to move along the risk-expected return frontier and take most of the benefits of diversification gains as higher returns by shifting their portfolios toward higher risk-higher expected return investments.

Consolidation may also affect systemic risk in part because it increases the sizes of the institutions. 
The systemic consequences of the failures of larger players may be more severe, spreading problems to more counterparties, particularly for institutions that are heavily involving in clearing and settlement functions. Larger institutions may also tend to fund themselves in ways that increase their reliance on intraday credit, which could increase the demand for intraday credit and increase systemic exposures. To some extent, these systemic problems created by larger institutions may be partially offset if the smaller number of larger institutions facilitates monitoring of risks by government supervisors or counterparty institutions. Some theoretical and empirical evidence suggests that the monitoring of banks by other banks may be an efficient mechanism for controlling systemic risk, and this task may be easier after consolidation (Rochet and Tirole 1996, Calomiris and Kahn 1996). Consolidation may also improve the efficiency of payments system risk management by economizing on the amount of collateral that needed to control risks on large-value transfer systems (Humphrey 1998).

Consolidation may also impose costs on the financial system by expanding the financial safety net. As discussed in Section 3, the safety net may provide additional protection to institutions considered "too big to fail," which may be created by consolidation. The safety net may also be extended when M\&As combine banking with nontraditional activities such as insurance and securities underwriting. Before deposit insurance created a formal safety net, banks tended to conduct their securities activities from separately incorporated and capitalized subsidiaries (Kroszner and Rajan 1997, Kroszner 1998). More recently, BHCs are moving eligible activities out of nonbank subsidiaries and into the bank or bank subsidiaries. One explanation is that BHCs are maximizing shareholder value by taking advantage of a net subsidy (gross subsidy net of regulatory costs) from the safety net that is positive at the margin (Kwast and Passmore 1998). A result may be to enhance the growth of the banking sector at the expense of competing financial service providers to a point that may represent a socially inefficient allocation of resources. Others argue that the net safety-net subsidy is minimal. One study argues against the widespread existence of a substantial safety net subsidy because permissible activities are not uniformly located within the bank or bank subsidiaries, and because banking organizations do not dominate these activities (Whalen 1997). The potential social costs of extending the safety net may be the greatest for combinations of banks with nonfinancial firms (Boyd, Chang, and Smith 1998), although there may be efficiency benefits of such combinations as discussed in 
Section 5 above. ${ }^{30}$

\subsubsection{New approaches to supervision}

One way to control the systemic risks and safety net subsidies that may accompany consolidation is through new approaches to the supervision of financial institutions. Recognizing that nontraditional activities and new financial instruments may increase the speed at which losses may occur as well as their magnitudes, efforts are underway to revamp the basic approach to bank supervision. The focus has begun to shift away from formulaic capital standards and mandated portfolio structures towards improvements in transparency and in the supervision of risk management systems. Supervisors may require that institutions have in place systems to monitor and control their own risk-taking. New capital requirements for market risk are based on banks' internal risk measurement models (Hendricks and Hirtle 1997), and new approaches to capital requirements for credit risk are under study (Jones and Mingo 1999). ${ }^{31}$ Another possibility is to increase market discipline through mandatory subordinated debt or other requirements (Flannery and Sorescu 1996, Calomiris 1997), or to consider broader safety net reform (Boyd 1999, Mishkin 1999).

\subsubsection{Operating structure}

The push for expanded bank powers in the U.S. has not yet been resolved in terms of the set of permissible bank activities or the future structure of financial institutions. The Citicorp-Travelers M\&A brings the issue of insurance powers to the forefront. The appropriate extent and location of banks' securities activities also remains an open question.

In the debate over operating structure in the U.S., the main contenders are the operating subsidiary model, in which nontraditional activities could be located in bank subsidiaries that are consolidated into the financial statement of a parent bank, and the holding company model, in which nontraditional activities must be located in nonbank subsidiaries of the BHC. The main argument in favor of the operating subsidiary

\footnotetext{
${ }^{30}$ To date, these potential costs have generally prevented combinations of banking and commerce in the U.S., although an exception is the unitary thrift charter which allows an institution to operate both financial and nonfinancial businesses (Kane 1999).

${ }^{31}$ An alternative which has not been adopted is the "pre-commitment" approach, whereby banks would commit to manage losses on trading activities such that these losses do not exceed a bank-specified amount of capital, and face penalties if they do not satisfy this commitment (Kupiec and O'Brien 1995).
} 
model is that it may be more efficient because of synergies from "common facilities, personnel, knowledge, brand name, etc." (Shull and White 1998). The main counterargument is that the holding company model may provide better protection against extension of the financial safety net (Kwast and Passmore 1998).

The operating subsidiary model may work well if appropriate firewalls can reasonably control the extension of the safety net while allowing institutions to choose an efficient structure. An important question, then, is whether firewalls between a bank and its subsidiaries can stand strong in time of crisis without negating the synergies associated with the operating subsidiary approach. It is likely that in times of crisis, poorly performing subsidiaries of either banks or BHCs will seek support from healthier affiliates or from the BHC to sustain themselves. The danger to the safety net is most pronounced when funds are transferred from an insured depository to an uninsured affiliate or subsidiary.

There may be reason to believe that such support will be given less frequently in the holding company model than the operating subsidiary model. The managers of an ailing BHC subsidiary may more likely meet the resistance of the managers of healthy subsidiaries. Acting in their self interest, managers of the healthy subsidiaries may fight plans for the reallocation of funds, thereby helping to support firewalls. If decision making in the operating subsidiary model is more centralized, it may more often be in the self interest of the decision maker to reallocate funds to assist an ailing operating subsidiary, and thus there is a greater likelihood of an extension of the safety net.

\subsubsection{Supervisory structure}

A related question is that of optimal supervisory structure. The holding company model would combine functional regulation (banking authorities regulate banking subsidiaries, securities authorities regulate securities subsidiaries, etc.) with umbrella oversight of the BHC. This supervisory structure permits functional regulators to focus on a narrow set of activities, maintain a high level of expertise, and possibly avoid imposing strong bank-like restrictions on other activities. The presence of an umbrella supervisor may also facilitate review of the institution as a whole and scrutiny of decision making, policies, and internal controls at the highest level (Kwast 1996b). In contrast, the operating subsidiary model avoids concentrating supervisory authority in a single umbrella supervisor. It fosters "regulatory competition" (Kane 1989) by permitting institutions to choose to operate as either banks or BHCs, thereby choosing the supervisory body 
to which they report.

The debates over operational and supervisory structures also concern the roles of the different supervisors. It has been argued that the control of systemic risk and the conduct of monetary policy both require the type of intimate involvement with the banking system that only a supervisor can maintain. To evaluate this claim, one study explored the link between confidential supervisory information and subsequent macroeconomic performance (Peek, Rosengren, and Tootell 1998a). They found that information on the proportion of U.S. banking assets in banks with composite CAMEL ratings of 5 (the worst rating) may help improve forecasts of future unemployment and inflation beyond what was incorporated in the predictions of private-sector forecasting firms, suggesting that supervisory data may be a valuable input into monetary policy making. A second study found that the examination data may also complement current-analysis forecasts by Federal Reserve staff (Peek, Rosengren, and Tootell 1998b).

\section{Implications for the future}

Based on existing trends and changes in economic environments, future consolidation will likely involve large financial institutions in different markets. We expect a continuation of nationwide consolidation of banks in the U.S., cross-border consolidation of financial institutions in the European Union, and consolidation of large banks with other large financial institutions worldwide. Takeovers by healthy institutions from other nations may also be part of the solution to the current problems in Asia and elsewhere. These types of consolidation, if they do occur, will be important in terms of the dollar values involved, potential consequences for customers and markets, and implications for policy and research. In this section, we briefly review the findings of the extant research literature, examine the implications for the likely consequences of future consolidation, and try to suggest useful avenues for future research.

\subsection{Brief review of the research findings}

The evidence reviewed here is admittedly mostly drawn from data sets on U.S. banks, although we have included as much nonbank and non-U.S. financial evidence as possible. The data are consistent with significant market power consequences of some types of in-market consolidation, but they also raise questions as to the importance of these effects. The static analyses suggest that concentration is associated with less favorable prices for some retail customers and possibly less efficiency for the firms providing these 
products, although some types of market power may be declining. The dynamic analyses suggest that prices become less favorable for consumers when market concentration increases dramatically, but the evidence is mixed for other types of M\&As. Importantly, concentration in local U.S. banking markets has declined slightly over time while large numbers of in-market M\&As were occurring, suggesting that other market and/or regulatory actions may have prevented large increases in local market power on a widespread basis. Consolidation appears to increase profit efficiency and help diversify the portfolio risks of the participants on average, and may have improved the economies in the areas in which these consolidations occurred. Although there was little or no cost efficiency improvement on average following M\&As, consolidations involving previously inefficient firms appeared to improve both cost and profit efficiency as the M\&A event itself may have "woken up" management to the need for improvement or may have been used as an excuse to implement unpleasant restructuring. The results of recent studies also suggest that there may be some scale, scope, and product mix efficiency gains available from consolidation, even among fairly large institutions, although the paucity of data on large institutions suggests more research is needed to verify the existence of these gains. There are also considerable potential positive and negative efficiency effects of combining banks with nonbanks, but little evidence to date on this topic.

The research also suggests that the effects of consolidation on the availability of services to small customers are likely to be small. Large banking organizations generally devote fewer of their assets to loans to small businesses, and M\&As involving large banks are generally found to reduce small business lending by the participants. However, some limited evidence suggests that other institutions in the same local market may make up most of the lost credit supply. In part, this external dynamic effect may be driven by de novo entry, given that de novo banks were found to lend more to small businesses as a percentage of assets than other small banks of comparable size. M\&As may also reduce service availability to small customers through branch office closings, although the limited evidence suggests these closures occur infrequently and generally occur when there is another branch office nearby.

There may also be systemic consequences of consolidation. Consolidation may improve the efficiency of the payments system by reducing the amount of payment information and instruments that need to be processed and transferred between financial institutions and by allowing faster adoption of electronic 
payments technologies. Consolidation may also impose costs on the financial system by increasing systemic risk or by expanding the financial safety net, although these costs may be offset to some extent by diversification of risks by individual institutions and by economies in monitoring and controlling the risks of a smaller number of institutions. Some of these concerns may also be partially alleviated by new approaches to the operating and supervisory structures of financial institutions.

\subsection{Implications for future consolidation}

These findings suggest mostly favorable efficiency consequences from the continued nationwide consolidation of the U.S. banking industry. The extension of branching networks through M\&As between banking organizations in different parts of the nation have the characteristics that would likely improve diversification of asset portfolios across regions, raise the performance of the economies in these regions, and increase payments system efficiency. Market power should not be a significant concern for most of these M\&As which join institutions in different parts of the nation, but may be a concern for some in-market M\&As that substantially raise local market concentration. There appear to be few likely negative social consequences from potential reductions of service availability to small customers. However, systemic risk and expansion of the safety net are significant concerns that may need to be addressed, given the sizes of the institutions involved.

If this U.S. experience is representative, similar benefits and costs from consolidation may be forthcoming from consolidation across Europe. However, to date there has been little intra-Europe international bank consolidation despite relatively few regulatory restrictions since 1993 . The implementation of monetary union may increase cross-border consolidation by increasing trade, by reducing the currency conversion costs of institutions operating in multiple nations, and by reducing costs to consumers of purchasing services from foreign-owned institutions. However, recent research also suggests that consolidation across borders in Europe may be inhibited by political factors, by institutional and cultural patterns, and differences in the use of paper versus book entry, settlement cycles and methods, and payments systems (Giddy, Saunders and Walter 1996, White 1998, Boot 1999). As well, European consolidation may be tempered by remaining structural differences among the capital markets, tax, and regulatory regimes of the European nations (Lannoo and Gros 1998). 
There may also be potential to resolve some the problems of financial institutions in Asia and other markets in financial distress through takeovers by healthy foreign institutions. This would be similar to some of the regulatory-induced and voluntary acquisitions of troubled banks and thrifts in the U.S. and elsewhere in the late 1980s and early 1990s. Nonetheless, to date there have been few foreign acquisitions of troubled institutions in Asia (exceptions include Merrill Lynch-Yamaichi Securities and Travelers-Nikko Securities), and it has been argued elsewhere that political forces may be resisting market forces pushing for consolidation (Kashyap 1999).

\subsection{Fruitful avenues for future research}

Our analyses of the causes, consequences, and policy implications of the consolidation of the financial services industry highlight the need for additional research and suggest some directions in which this research might proceed. Most of the empirical research on financial services consolidation has focused on U.S. banking organizations, and much of this has used data from the 1980s or early 1990s that may not well represent the consolidation of the future. We suggest that future studies focus on recent data from many nations, and data on large institutions that are likely to be involved in future consolidation activity.

To be most relevant, future research should also focus attention on M\&As stemming from the causes that are behind the current consolidation wave of the 1990s. Deregulation of geographic and product markets has spurred much of the consolidation of the 1990s, so future research should put additional emphasis on the effects of M\&As of non-bank institutions, M\&As that cross industry lines, and M\&As that cross international borders. M\&As between large banks and large nonbanking institutions can create institutions with substantial potential synergies, but can create potentially large systemic risk and financial safety net consequences as well. More research on the effects of such consolidations will be needed before conclusions can be drawn. In addition to studying the continued nationwide consolidation of the U.S. banking industry, future research should explore the consolidation of the European banking industry, the potential for foreign acquisition of financially distressed institutions in Asia and elsewhere, and M\&As between large banking organizations and other types of financial service providers worldwide.

Finally, most of the past research has employed static analysis methods, which do not use data on M\&As but instead relate the potential consequences of consolidation (market power, efficiency, service 
availability, etc.) to characteristics of financial institutions that are associated with consolidation (e.g., institution size). Future research should more often employ dynamic analysis methods that evaluate the consequences of consolidation by comparing the behavior of financial institutions before and after M\&As or by comparing the behavior of recently consolidated institutions with other institutions. Future research should endeavor to include the external effects of consolidation as well - the consequences of M\&As on the market power, efficiency, service provision, etc. of other firms in the affected markets - which were often excluded from past studies. 


\section{REFERENCES}

Akhavein, J.D., Berger, A.N., Humphrey, D.B., 1997. The effects of megamergers on efficiency and prices: evidence from a bank profit function, Review of Industrial Organization 12, 95-139.

Allen, F., Gale, D., 1997. Financial markets, intermediaries, and intertemporal smoothing, Journal of Political Economy 105(3), 523-45.

Allen, L., Ceboyan, A.S., 1991. Bank acquisitions and ownership structure: Theory and evidence, Journal of Banking and Finance 15, 425-48.

Allen, L., Saunders, A., Udell, G.F., 1991. The pricing of retail deposits: concentration and information. Journal of Financial Intermediation 1, 335-361.

Altunbas, Y., Maude, D., Molyneux, P., 1995. Efficiency and mergers in the UK (retail) banking market, working paper, Bank of England.

Amel, D.F., Liang, J.N., 1992. The relationship between entry into banking markets and changes in legal restrictions on entry, The Antitrust Bulletin 37, 631-649.

Amel, D.F., Liang, J.N., 1997. Determinants of entry and profits in local banking markets, Review of Industrial Organization 12, 59-78.

Amel, D.F., Hannan, T.H., 1998. Establishing banking market definitions through estimation of residual deposit supply equations, working paper, Board of Governors of the Federal Reserve System.

Ang, J.S., Richardson, T., 1994. The underwriting experience of commercial bank affiliates prior to the Glass-Steagall Act: A re-examination of evidence for passage of the Act, Journal of Banking and Finance 18, 351-395.

Angelini, P., Salvo, R.D., Ferri, G., 1998. Availability and cost for small businesses: customer relationships and credit cooperatives, Journal of Banking and Finance 22, 929-954.

Asdrubali, P., Sørensen, B.E., Yosha, O., 1996. Channels of interstate risk sharing: United States 1963-90, Quarterly Journal of Economics 111, 1081-1110.

Avery, R., Bostic, R., Calem, P., Canner, G., 1999. Consolidation and depositor services, Journal of Banking and Finance 23.

Avery, R., Bostic R.W., Samolyk, K.A., 1998. The evolution of small business finance: The role of personal wealth, Journal of Banking and Finance 22, 1019-1061.

Bauer, P.W., Berger, A.N., Humphrey, D.B., 1993. Efficiency and productivity growth in U.S. banking, in H.O. Fried, C.A.K. Lovell, and S.S. Schmidt, eds., The measurement of productive efficiency: Techniques and applications, Oxford: Oxford University Press, 386-413.

Bauer, P.W., Ferrier, G.D., 1996. Efficiency measurement issues for payments processing, Journal of Money, Credit and Banking 28, 1004-39.

Bauer, P.W., Hancock, D., 1993. The efficiency of the Federal Reserve in providing check processing services, Journal of Banking and Finance 17, 287-311. 
Bauer, P.W., Hancock, D., 1995. Scale economies and technical change in the Federal Reserve automated clearinghouse payment processing, Federal Reserve Bank of Cleveland Economic Review 33, 14-29.

Benston, G.J., Hunter, W.C., Wall, L.D., 1995. Motivations for bank mergers and acquisitions: Enhancing the deposit insurance put option versus earnings diversification, Journal of Money, Credit, and Banking 27, 777-788.

Berger, A.N., 1995. The profit-structure relationship in banking -- Tests of market-power and efficientstructure hypotheses, Journal of Money, Credit, and Banking, 27, 404-31.

Berger, A.N., 1998. The efficiency effects of bank mergers and acquisition: A preliminary look at the 1990s data, edited by Y. Amihud and G. Miller, Bank Mergers \& Acquisitions, Kluwer Academic (Boston, MA), 79-111.

Berger, A.N., Bonime, S.D., Covitz, D.M., Hancock, D., 1998. The extraordinary persistence of profits in the U.S. banking industry: A breakdown of the competitive paradigm?, working paper, Board of Governors of the Federal Reserve System.

Berger, A.N., Hancock, D., Humphrey, D.B., 1993. Bank efficiency derived from the profit function, Journal of Banking and Finance 17, 317-47.

Berger, A.N., Hancock, D., Marquardt, J.C., 1996. A framework for analyzing efficiency, risks, costs, and innovations in the payments system, Journal of Money, Credit and Banking 28, 696-732.

Berger, A.N., Hannan, T.H., 1989. The price-concentration relationship in banking, Review of Economics and Statistics 71, 291-299.

Berger, A.N., Hannan, T.H., 1997. Using measures of firm efficiency to distinguish among alternative explanations of the structure-performance relationship, Managerial Finance 23, 6-31.

Berger, A.N., Hannan, T.H., 1998. The efficiency cost of market power in the banking industry: A test of the 'quiet life' and related hypotheses, Review of Economics and Statistics 80, 454-65.

Berger, A.N., Hanweck, G.A., Humphrey, D.B., 1987. Competitive viability in banking: Scale, scope, and product mix economies, Journal of Monetary Economics 20, 501-520.

Berger, A.N., Humphrey, D.B., 1988. Interstate banking and the payment system, Journal of Financial Services Research 1, 131-45.

Berger, A.N., Humphrey, D.B., 1991. The dominance of inefficiencies over scale and product mix economies in banking, Journal of Monetary Economics 28, 117-48.

Berger, A.N., Humphrey, D.B., 1992. Megamergers in banking and the use of cost efficiency as an antitrust defense, Antitrust Bulletin 37, 541-600.

Berger, A.N., Humphrey, D.B., 1997. Efficiency of financial institutions: International survey and directions for future research, European Journal of Operational Research 98, 175-212.

Berger, A.N., Humphrey, D.B., Pulley, L.B., 1996. Do consumers pay for one-stop banking? Evidence from an alternative revenue function, Journal of Banking and Finance 20, 1601-21. 
Berger, A.N., Kashyap, A.K., Scalise, J.M., 1995. The transformation of the U.S. banking industry: What a long, strange trip it's been, Brookings Papers on Economic Activity 2, 55-218.

Berger, A.N., Leusner, J.H., Mingo, J.J., 1997. The efficiency of bank branches, Journal of Monetary Economics 40, 141-162.

Berger, A.N., Mester, L.J., 1997. Inside the black box: What explains differences in the efficiencies of financial institutions?, Journal of Banking and Finance 21, 895-947.

Berger, A.N., Saunders, A., Scalise, J.M., Udell, G.F., 1998. The effects of bank mergers and acquisitions on small business lending, Journal of Financial Economics 50.

Berger, A.N., Udell, G.F., 1995. Relationship lending and lines of credit in small firm finance, Journal of Business 68, 351-382.

Berger, A.N., Udell, G.F., 1996. Universal banking and the future of small business lending, edited by A. Saunders and I. Walter, Financial system design: The case for universal banking, Burr Ridge, IL, Irwin Publishing, 559-627.

Berger, A.N., Udell, G.F., 1998. The Economics of Small Business Finance: The Roles of Private Equity and Debt Markets in the Financial Growth Cycle, Journal of Banking and Finance 22, 613-73.

Berger, P.G., Ofek, E., 1995. Diversification's effect on firm value, Journal of Financial Economics 37, 39-65.

Berlin, M., Mester, L.J., 1998. On the profitability and cost of relationship lending, Journal of Banking and Finance 22, 873-897.

Bhargava, R., Fraser, D.R., 1998. On the wealth and risk effects of commercial bank expansion into securities underwriting: An analysis of Section 20 subsidiaries, Journal of Banking and Finance 22, 447-465.

Bhattacharya, A., Lovell, C.A.K., Sahay, P., 1997, The impact of liberalization on the productive efficiency of Indian commercial banks, European Journal of Operational Research, 98, 332-345.

Blackwell, D., Winters, D.B., 1997. Banking relationships and the effect of monitoring on loan pricing, Journal of Financial Research 20, 275-89.

Board of Governors of the Federal Reserve System, May 1988. Senior loan officer opinion survey on bank lending practices.

Boot, A.W.A., 1999. European lessons on consolidation in banking, Journal of Banking and Finance 23.

Boot, A.W.A., Thakor A.V., 1996. Banking structure and financial innovation. In Saunders, A., Walter I. (Eds.), Universal Banking: Financial System Design Reconsidered. Irwin, Chicago, pp. 161-204.

Bostic, R.W., Canner, G.B., 1998. New information on small business and small farm lending: The 1996 CRA data, Federal Reserve Bulletin 84, 1-21. 
Boyd, J.H., 1999. Expansion of commercial banking powers --- Or, universal banking is the cart, not the horse, Journal of Banking and Finance 23.

Boyd, J.H., Chang, C., Smith, B.D., 1998. Moral hazard under commercial and universal banking, Federal Reserve Bank of Minneapolis Working Paper No. 585.

Boyd, J.H., Gertler, M., 1994. Are banks dead? Or, are the reports greatly exaggerated? in The Declining Role of Banking, Federal Reserve Bank of Chicago, Proceedings of the 30th Annual Conference on Bank Structure and Competition, 85-117.

Boyd, J.H., Graham, S.L., Hewitt, S.R., 1993. Bank holding company mergers with nonbank financial firms: effects on the risk of failure, Journal of Banking and Finance 17(1), 43-63.

Calem, P., 1994. The impact of geographic deregulation on small banks, Business Review, Federal Reserve Bank of Philadelphia.

Calomiris, C.W., 1997. The postmodern bank safety net: Lessons from developed and developing countries, American Enterprise Institute: Washington, DC.

Calomiris, C.W., 1999. Gauging the efficiency of bank consolidation during a merger wave, Journal of Banking and Finance 23.

Calomiris, C.W., Kahn, C.M., 1996. The efficiency of cooperative interbank relations: The Suffolk system, Journal of Money, Credit and Banking 28, 766-97.

Calomiris, C.W., Karceski, J., 1998. Is the bank merger wave of the 1990s efficient? Lessons from nine case studies, in Mergers and Productivity, (S. Kaplan, ed.), University of Chicago Press.

Chamberlain, S.L., 1998. The effect of bank ownership changes on subsidiary-level earnings, edited by Y. Amihud and G. Miller, Bank Mergers \& Acquisitions, Kluwer Academic (Boston, MA), 137-172.

Chang, C.E., Hasan, I., Hunter, W.C., 1998. Efficiency of multinational banks: An empirical investigation, Applied Financial Economics 8, 1-8.

Chowdhry, B., Nanda, V., 1996. Stabilization, syndication and pricing of IPOs, Journal of Financial and Quantitative Analysis 31, 25-42.

Clark, J., 1996. Economic cost, scale efficiency and competitive viability in banking, Journal of Money, Credit, and Banking 28, 342-64.

Clark, J., Siems, T.F., 1997. Competitive viability in banking: Looking beyond the balance sheet, Financial Industry Studies Working Paper No. 5-97, Federal Reserve Bank of Dallas.

Cole, R.A., 1998. The importance of relationships to the availability of credit, Journal of Banking and Finance 22, 959-77.

Cole, R.A., Goldberg, L.G., White, L.J., 1997. Cookie-cutter versus character: The micro structure of small business lending by large and small banks, New York University working paper.

Cole, R.A., Walraven, N., 1998. Banking consolidation and the availability of credit to small business, 
Federal Reserve Board working paper.

Cornett, M.M., Hovakimian, G., Palia, D., Tehranian, H., 1998. The impact of the manager-shareholder conflict on acquiring bank returns, mimeo, 1998.

Cornett, M.M., Tehranian, H., 1992. Changes in corporate performance associated with bank acquisitions, Journal of Financial Economics 31, 211-34.

Cosimano, T.F., McDonald, B., 1998. What's different among banks?, Journal of Monetary Economics 41, $57-70$.

Craig, B.R., Santos, J.A.C., 1997. Banking consolidation: Impact on small business lending, working paper, Federal Reserve Bank of Cleveland.

Cummins, J.D., Tennyson, S.L., Weiss, M.A., 1999. Efficiency scale economies and consolidation, Journal of Banking and Finance 23.

Cummins, J.D., Weiss, M.A., 1999. Analyzing firm performance in the insurance industry using frontier efficiency methods, in G. Dionne, ed., Handbook of Insurance Economics (Boston: Kluwer Academic).

Cummins, J.D., Zi, H., 1998. Comparison of frontier efficiency methods: An application to the U.S. Life Insurance Industry, Journal of Productivity Analysis.

Cybo-Ottone, A., Murgia, M., 1998. Mergers and shareholder wealth in European banking, working paper, Associazione Bancaria Italiana.

Cyrnak, A., Hannan, T.H., 1998. Bank lending to small businesses and the use of CRA loan data to measure market structure, Federal Reserve Board working paper.

DeLong, G.L., 1998. Domestic and international bank mergers: The gains from focusing versus diversifying, New York University working paper.

DeLong, G.L., Smith, R.C., Walter, I., 1998. Global merger and acquisition tables 1997, Solomon Center, New York University.

Demsetz, R.S., Strahan, P.E., 1997. Diversification, size, and risk at bank holding companies, Journal of Money, Credit, and Banking 29, 300-313.

DeYoung, R., 1997. Bank mergers, X-efficiency, and the market for corporate control, Managerial Finance $23,32-47$.

DeYoung, R., 1998. Comment on Goldberg and White, Journal of Banking and Finance 22, 868-872.

DeYoung, R., Goldberg, L.G., White, L.J., 1999. Youth, adolescence, and maturity at banks: Credit availability to small business in an era of banking consolidation, Journal of Banking and Finance 23.

DeYoung, R., Hasan, I., 1998. The performance of de novo commercial banks: A profit efficiency approach, Journal of Banking and Finance 22, 565-87. 
DeYoung, R., Hasan, I., Kirchhoff, B., 1998. The impact of out-of-state entry on the cost efficiency of local commercial banks, Journal of Economics and Business 50, 191-203.

DeYoung, R., Nolle, D., 1996. Foreign-owned banks in the U.S.: Earning market share or buying it? Journal of Money, Credit, and Banking 28, 622-36.

Eisenbeis, R.A., 1999. Comment on Peek, Rosengren and Kasirye, Journal of Banking and Finance 23.

Elsas, R., Krahnen, J.P., 1997. Is relationship lending special? Evidence from credit-file data in Germany, Working Paper, Johann Wolfgang Goethe-University Frankfurt.

English, M., Hayes, K., 1991. A simple test of market power, Working paper, Southern Methodist University, Dallas, TX.

Esty, B.C., Narasimhan, B., Tufano, P., 1999. Interest-rate exposure and bank mergers, Journal of Banking and Finance 23.

Fama, E., 1985. What's different about banks?, Journal of Monetary Economics 17, 29-39.

Fazzari, S.M., Hubbard, R.G., Petersen, B.C., 1988. Financing constraints and corporate investment, Brookings Papers on Economic Activity 1, 141-95.

Ferrier, G., 1999. Comment on Hughes, Lang, Mester and Moon and Cummins, Tennyson, and Weiss, Journal of Banking and Finance 23.

Ferrier, G., Grosskopf, S., Hayes, K., Yaisawarng, S., 1993. Economies of diversification in the banking industry: A frontier approach, Journal of Monetary Economics, 31, 229-49.

Ferrier, G., Lovell, C.A.K., 1990, Measuring cost efficiency in banking: Econometric and linear programming evidence, Journal of Econometrics, 46, 229-45.

Fixler, D.J., Zieschang, K.D., 1993. An index number approach to measuring bank efficiency: An application to mergers, Journal of Banking and Finance 17, 437-50.

Flannery, M.J., 1998. Comment on Benveniste, Erdal, and Wilhelm, Jr., Journal of Banking and Finance 22, 768-772.

Flannery, M.J., 1999. Comment on Milbourn, Boot, and Thakor, Journal of Banking and Finance 23.

Flannery, M.J., Sorescu, S.M., 1996., Evidence of bank market discipline in subordinated debenture yields: 1983-1991, Journal of Finance 51, 1347-1377.

Focarelli, D., Panetta, F., Salleo, C., 1998. Why do banks merge: Some empirical evidence from Italy, mimeo, 1998.

Frei, F., Harker, P., 1996. Measuring the efficiency of service delivery processes: With applications to retail banking, Working paper no. 96-31, Wharton Financial Institutions Center.

Frei, F., Harker, P., Hunter, L., 1995. Performance in consumer financial services organizations: Framework and results from the pilot study, Working paper no. 95-03, Wharton Financial Institutions Center. 
Fried, H.O., Lovell, C.A.K., Yaisawarng, S., 1999. The impact of mergers on credit union service provision, Journal of Banking and Finance 23.

Frieder, L.A., Sherrill, P., 1997, Customer value management: Decision support and knowledge management as the missing links, Proceedings of a Conference on Bank Structure and Competition, Federal Reserve Bank of Chicago, 76-85.

Froot, K.A., Stein, J.C., 1991. Exchange rates and foreign direct investment: An imperfect capital markets approach, Quarterly Journal of Economics 106, 1191-1218.

Gande, A., Puri, M., Saunders, A., 1998. Bank entry, competition and the market for corporate securities underwriting, mimeo, February 1998.

Gande, A., Puri, M., Saunders, A., Walter, I., 1997. Bank underwriting of Debt securities: Modern evidence, The Review of Financial Studies 10(4), 1175-1202.

Gardner, L., Grace, M., 1993. X-Efficiency in the U.S. life insurance industry, Journal of Banking and Finance 17, 497-510.

Garmaise, M., 1997, Informed investors and the financing of entrepreneurial projects, Stanford University working paper.

Giddy, I.H., Saunders, A., Walter, I., 1996. European financial market integration: Clearance and settlement issues, Journal of Money, Credit and Banking 28, 986-1000.

Goldberg, L.G., Hanweck, G.A., Keenan, M., Young, A., 1991. Economics of scale and scope in the securities industry, Journal of Banking and Finance 15, 91-107.

Goldberg, L.G., White, L.J., 1998. De novo banks and lending to small businesses, Journal of Banking and Finance 22, 851-867.

Grace, M., Timme, S.G., 1992. An examination of cost economies in the United States life Insurance Industry, Journal of Risk and Insurance, 59, 72-103.

Hadlock, C.J., Houston, J.F., Ryngaert, M., 1999. The role of managerial incentives in bank acquisitions, Journal of Banking and Finance 23.

Hancock, D., 1986. A model of the financial firm with imperfect asset and deposit elasticities, Journal of Banking and Finance 10, 37-54.

Hancock, D., Humphrey, D.B., 1998. Payment transactions, instruments, and systems: A survey, Journal of Banking and Finance 21, 1573-1624.

Hancock, D., Humphrey, D.B., Wilcox, J.A., 1999. Telecommunication versus processing cost and the consolidation of the payments system, Journal of Banking and Finance 23.

Hancock, D., Wilcox, J.A., 1998. The "credit crunch" and the availability of credit to small business, Journal of Banking and Finance 22, 983-1014.

Hannan, T.H., 1991, Bank commercial loan markets and the role of market structure: Evidence from surveys 


$$
\mathrm{R}-8
$$

of commercial lending, Journal of Banking and Finance 15, 133-149.

Hannan, T.H., 1994. Asymmetric price rigidity and the responsiveness of customers to price changes: The case of deposit interest rates, Journal of Financial Services Research 8, 257-67.

Hannan, T.H., 1997. Market share inequality, the number of competitors, and the HHI: An examination of bank pricing, Review of Industrial Organization 12, 23-35.

Hannan, T.H., 1998. Bank fees and their variation across banks and locations, Working paper, Federal Reserve Board.

Hannan, T.H., Berger, A.N., 1991. The rigidity of prices: Evidence from the banking industry, American Economic Review 81, 938-945.

Hannan, T.H., Liang, J.N., 1993. Inferring market power from time-series data: The case of the banking firm, International Journal of Industrial Organization 11, 205-218.

Hannan, T.H., Liang, J.N., 1995. The influence of thrift competition on bank business loan rates, Journal of Financial Services Research 9, 107-22.

Hannan, T.H., McDowell, J.M., 1984. The determinants of technology adoption: The case of the banking firm, Rand Journal of Economics 15, 328-335.

Hannan, T.H., Wolken, J.D., 1989, Returns to bidders and targets in the acquisition process: Evidence from the banking industry, Journal of Financial Services Research 3, 5-16.

Haynes, M., Thompson, S., 1997. The productivity effects of bank mergers: Evidence from the UK building societies, mimeo, 1997.

Harhoff, D., Korting, T., 1997. Lending relationships in Germany: Empirical results from survey data, working paper.

Hasan, I., Hunter, W.C., 1996. Efficiency of Japanese Multinational Banks in the United States, Research in Finance 14 (JAI Press: Greenwich, Connecticut), 157-173.

Hendricks, D.E., 1999. Comment on Hancock, Humphrey and Wilcox, Journal of Banking and Finance 23.

Hendricks, D.E., Hirtle, B.J., 1997. Bank capital requirements for market risk: The internal models approach, Federal Reserve Bank of New York Economic Policy Review 3(4), 1-12.

Hester, D, 1979. Customer relationships and terms of loans: Evidence from a pilot survey, Journal of Money, Credit and Banking 11,349-357.

Hoshi, T., Kashyap, A.K, Sharfstein, D., 1990. The role of banks in reducing the costs of financial distress in Japan, Journal of Financial Economics 27, 67-88.

Hoshi, T., Kashyap, A.K, Scharfstein, D., 1991. Corporate structure, liquidity and investment: Evidence from Japanese industrial groups, Quarterly Journal of Economics 106(1), 33-60.

Houston, J.F., James, C.M., 1998. Do bank internal capital markets promote lending?, Journal of Banking 
and Finance 22, 899-918.

Houston, J.F., James, C.M., Marcus, D., 1997. Capital market frictions and the role of internal capital markets in banking, 1999 Journal of Financial Economics 46, 135-164.

Houston, J.F., Ryngaert, M.D., 1994. The overall gains from large bank mergers, Journal of Banking and Finance 18, 1155-76.

Houston, J.F., Ryngaert, M.D., 1996. The value added by bank acquisitions: Lessons from Wells Fargo's acquisition of First Interstate, Journal of Applied Corporate Finance 9, 74-82.

Houston, J.F., Ryngaert, M.D., 1997. Equity issuance and adverse selection: A direct test using conditional stock offers, Journal of Finance 52.

Hubbard, G., 1999. Comment on Hadlock, Houston and Ryngaert, Journal of Banking and Finance 23.

Hubbard, R., Kuttner, K., Palia, D., 1998. Are there bank effects in borrowers' costs of funds? Evidence from a matched sample of borrowers and banks. Unpublished working paper, Columbia University.

Hubbard, R.G., Palia, D., 1995. Executive pay and performance: Evidence from the U.S. banking industry, Journal of Financial Economics 39, 105-30.

Hughes, J.P., Lang, W., Mester, L.J., Moon, C.-G., 1996. Efficient banking under interstate branching, Journal of Money, Credit, and Banking, 28, 1043-1071.

Hughes, J.P., Lang, W., Mester, L.J., Moon, C.-G., 1997. Recovering risky technologies using the almost ideal demand system: An application to U.S. banks," Federal Reserve Bank of Philadelphia Working Paper No. 97-8.

Hughes, J.P., Lang, W., Mester, L.J., Moon, C.-G., 1999. The dollars and sense of bank consolidation, Journal of Banking and Finance 23.

Hughes, J.P., Mester, L.J., 1998. Bank capitalization and cost: Evidence of scale economies in risk management and signaling, Review of Economics and Statistics.

Humphrey, D.B., 1982. Costs, scale economies, competition, and product mix in the U.S. payments mechanism, staff study, Board of Governors of the Federal Reserve System, 1-18.

Humphrey, D.B., 1998. Advances in financial market clearing and settlement, Brookings-Wharton Papers on Financial Services, edited by R.E. Litan and A.M. Santomero, Brookings Institution Press, Washington, DC.

Humphrey, D.B., Berger, A.N., 1990. Market failure and resource use: Economic incentives to use different payment instruments, The U.S. Payment System: Efficiency, Risk, and the Role of the Federal Reserve, edited by D.B. Humphrey, Norwell, MA: Kluwer Academic, 45-86.

Humphrey, D.B., Pulley, L.B., 1997. Banks' responses to deregulation: Profits, technology, and efficiency, Journal of Money, Credit, and Banking 29.

Humphrey, D.B., Pulley, L.B., Vesala, J.M., 1996. Cash, paper, and electronic payments: A cross country 


$$
\mathrm{R}-10
$$

analysis, Journal of Money, Credit and Banking 28, 914-39.

Humphrey, D.B., Pulley, L.B., Vesala, J.M., 1998. The check's in the mail: Why the U.S. lags in the adoption of cost-saving electronic payments, working paper, Florida State University.

Hunter, W.C., Timme, S.G., 1986. Technical change, organizational form, and the structure of bank productivity, Journal of Money, Credit and Banking 18, 152-66.

Hunter, W.C., Timme, S.G., Yang, W.K., 1990. An examination of cost subadditivity and multiproduct production in large U.S. banks, Journal of Money, Credit and Banking 22, 504-25.

Jackson, W.E. III, 1997. Market structure and the speed of price adjustments: Evidence of non-monotonicity, Review of Industrial Organization 12, 37-57.

James, C.M., 1999. Comment on Esty, Narasimhan and Tufano, Journal of Banking and Finance 23.

Jayaratne, J., Strahan, P.E., 1996. The finance-growth nexus: Evidence from bank branch deregulation,+ Quarterly Journal of Economics 111, 639-70.

Jayaratne, J., Strahan, P.E., 1998. Entry restrictions, industry evolution and dynamic efficiency: Evidence from commercial banking, Journal of Law and Economics 49, 239-74.

Jayaratne, J., Wolken, J.D., 1999. How important are small banks to small business lending? New evidence from a survey to small businesses, Journal of Banking and Finance 23.

Jensen, M.C., 1986. Agency costs of free cash flow, corporate finance, and takeovers, American Economic Review Papers and Proceedings 76, 323-29.

John, K., Ofek, E., 1995. Asset sales and increase in focus, Journal of Financial Economics 37, 105-126.

Johnson, H.G., 1968. Problems of efficiency in monetary management, Journal of Political Economy 76, 971-990.

Jones, D., Mingo, J., 1999. Credit risk modeling and internal capital allocation processes: Implications for a models-based regulatory bank capital standard, Journal of Economics and Business.

Kanatas, G., 1987. Commercial paper, bank reserve requirements, and the informational role of loan commitments, Journal of Banking and Finance 11, 425-448.

Kane, E.J., 1989. How market forces influence the structure of financial regulation, in W.S. Haraf and R.M. Kushmeider, eds. Restructuring Banking and Financial Services in America, American Enterprise Institute for Public Policy Research, Washington, D.C.

Kane, E.J., 1996. De jure interstate banking: Why only now? Journal of Money, Credit, and Banking 28(2), 141-61.

Kane, E.J., 1999. Implications of superhero metaphors for the issue of banking powers, Journal of Banking and Finance 23.

Kaplan, S., Zingales, L., 1997. Do investment-cash flow sensitivities provide useful Measures of financing 


$$
\mathrm{R}-11
$$

constraints?, Quarterly Journal of Economics, 169-215.

Kashyap, A.K, 1999. What should regulators do about merger policy?, Journal of Banking and Finance 23.

Keeton, W.R., 1995. Multi-office bank lending to small businesses: Some new evidence, Federal Reserve Bank of Kansas City Economic Review 80 (2), 45-57.

Keeton, W.R., 1996. Do bank mergers reduce lending to businesses and farmers? New evidence from tenth district states, Federal Reserve Bank of Kansas City, Economic Review 81 (3): 63-75.

Keeton, W.R., 1997. The effects of mergers on farm and business lending at small banks: New evidence from tenth district states, working paper, Federal Reserve Bank of Kansas City.

Kolari, J., Zardkoohi, A., 1997. The impact of structural change in the banking industry on small business lending, Report to the Small Business Administration (a).

Kolari, J., Zardkoohi, A., 1997. Bank acquisitions and small business lending, working paper, Texas A\&M University (b).

Kroszner, R.S., 1998. Rethinking bank regulation: A review of the historical evidence, Journal of Applied Corporate Finance 11 (2), 48-58.

Kroszner, R.S., 1999. Comment on Saunders and Wilson, Journal of Banking and Finance 23.

Kroszner, R.S., Rajan, R.G., 1994. Is the Glass-Steagall act justified?, A study of the U.S. experience with universal banking before 1933, American Economic Review 84(4), 810-832.

Kroszner, R.S., Rajan, R.G., 1997. Organizational structure and credibility: Evidence from commercial bank securities activities before the Glass-Steagall Act, Journal of Monetary Economics 39, 475516.

Kroszner, R.S., Strahan, P.E., 1997. The political economy of deregulation: Evidence from the relaxation of bank banking restrictions in the United States, Federal Reserve Bank of New York, research paper no. 9720 .

Kupiec, P.H., O'Brien, J.M., 1995. A pre-commitment approach to capital requirements for market risk, Board of Governors of the Federal Reserve System, Finance and Economics Discussion Series 36.

Kwan, S.H., 1997. Securities activities by commercial banking firms' section 20 subsidiaries: Risk, return, and diversification benefits," mimeo, Federal Reserve Bank of San Francisco, October 1997.

Kwast, M.L., 1989. The impact of underwriting and dealing on bank returns and risks, Journal of Banking and Finance 13, 101-125.

Kwast, M.L., 1996. United States banking consolidation: Current trends and issues, paper presented at OECD conference, November (a).

Kwast, M.L., 1996. Supervising the universal bank, edited by A. Saunders and I. Walter, Financial system design: The case for universal banking, Burr Ridge, IL, Irwin Publishing, 743-749 (b). 
Kwast, M.L., 1999. Bank mergers: What should policymakers do?, Journal of Banking and Finance 23.

Kwast, M.L., Passmore, S.W., 1998. The subsidy provided by the Federal Safety Net: Theory, measurement, and containment, Proceedings of a Conference on Bank Structure and Competition, Federal Reserve Bank of Chicago.

Kwast, M.L., Starr-McCluer, M., Wolken, J., 1997. Market definition and the analysis of antitrust in banking, Antitrust Bulletin, 42, 973-995.

Lamont, O., 1996. Cash flow and investment: Evidence from internal capital markets, Journal of Finance 52, 83-109.

Lang, G., Welzel, P., 1998. Technology and cost efficiency in universal banking: A thick frontier approach, Journal of Productivity Analysis 10, 63-84.

Lang, L.H.P., Stulz, R.E., 1994. Tobin's q, corporate diversification and firm performance, Journal of Political Economy.

Lannoo, K., Gros, D., 1998. Capital Markets and EMU: Report of a CEPS Working Party, Centre for European Policy Studies.

Levonian, M., Soller, J., 1995. Small banks, small loans, small business, Federal Reserve Bank of San Francisco working paper.

Linder, J.C., Crane, D.B., 1992. Bank mergers: Integration and profitability, Journal of Financial Services Research 7, 35-55.

Llewellyn, D.T., 1996. Universal banking and the public interest: A British perspective. In Saunders, A., Walter I. (Eds.), Universal Banking: Financial System Design Reconsidered. Irwin, Chicago, pp. 161-204.

Mahajan, A., Rangan, N., Zardkoohi, A., 1996. Cost structures in multinational and domestic banking, Journal of Banking and Finance 20, 238-306.

Matutes, C., Padilla, A.J., 1994. Shared ATM networks and banking competition, European Economic Review 38, 1113-38.

Maudos, J., 1996. Market structure and performance in Spanish banking using a direct measure of efficiency, working paper, University of Valencia, Valencia, Spain.

McAllister, P.H., McManus, D.A., 1993. Resolving the scale efficiency puzzle in banking, Journal of Banking and Finance 17, 389-405.

McLaughlin, S., 1995. The impact of interstate banking and branching reform: Evidence from the States, Current Issues in Economics and Finance 1.

Mester, L.J, 1987. Multiple market contact between savings and loans, Journal of Money, Credit, and Banking 19, 538-49. 


$$
\mathrm{R}-13
$$

Mester, L.J, 1992. Perpetual signaling with imperfectly correlated costs, RAND Journal of Economics 23 , 548-63(a).

Mester, L.J., 1992. Traditional and nontraditional banking: An information-theoretic approach, Journal of Banking and Finance 16, 545-566(b).

Mester, L.J., 1993. Efficiency in the savings and loan industry, Journal of Banking and Finance 17, 267-86.

Mester, L.J., Nakamura, L.I., Renault, M., 1998. Checking accounts and bank monitoring, Federal Reserve Bank of Philadelphia working paper.

Meyer, L.H., 1998. Statement before the Committee on Banking and Financial Services, U.S. House of Representatives, April 29.

Milbourn, T.T., Boot, A.W.A., Thakor, A.V., 1999. Megamergers and expanded scope: Theories of bank size and activity diversity, Journal of Banking and Finance 23.

Mishkin, F.S., 1999. Financial consolidation: Dangers and opportunities, Journal of Banking and Finance 23.

Moore, R.R., Siems, T.F., 1998. Bank mergers: Creating value of destroying competition? Federal Reserve Bank of Dallas, Financial Industry Issues, third quarter.

Morgan, D.P., 1998. Bank mergers, efficiency, and diversification, working paper, Federal Reserve Bank of New York.

Nakamura, L.I., 1993. Commercial bank information: Implications for the structure of banking, in M. Klausner and L.J. White, editors, Structural change in banking, Homewood, IL: Irwin, 131-160.

Neumark, D., Sharpe, S.A., 1992. Market structure and the nature of price rigidity: Evidence from the market for consumer deposits, Quarterly Journal of Economics 107, 657-80.

Noulas, A.G., Ray, S.C., Miller, S.M., 1990. Returns to scale and input substitution for large U.S. banks, Journal of Money, Credit, and Banking, 22, 94-108.

Ongena, S., and D. Smith, 1997. Empirical evidence on the duration of banking relationships, working paper, Norwegian School of Management.

Peek, J., Rosengren, E.S., 1996. Small business credit availability: How important is size of lender?, edited by A. Saunders and I. Walter, Financial System Design: The Case for Universal Banking, Burr Ridge, IL, Irwin Publishing, 628-55.

Peek, J., Rosengren, E.S., Kasirye, F., 1999. The poor performance of foreign bank subsidiaries: Were the problems acquired or created?, Journal of Banking and Finance 23.

Peek, J., Rosengren, E.S., Tootell, G.M.B., 1998. Does the Federal Reserve have and informational advantage?, You Can Bank on It, Federal Reserve Bank of Boston working paper 98-2 (a).

Peek, J., Rosengren, E.S., Tootell, G.M.B., 1998. Is bank supervision central to central banking? Federal Reserve Bank of Boston working paper (b). 


$$
\mathrm{R}-14
$$

Peristiani, S., 1993. The effects of mergers on bank performance, Federal Reserve Bank of New York Studies on Excess Capacity in the Financial Sector, March 1993.

Peristiani, S., 1997. Do mergers improve the X-efficiency and scale efficiency of U.S. banks? Evidence from the 1980s, Journal of Money, Credit, and Banking 29, 326-37.

Peristiani, S., 1999. Comment on Fried, Lovell and Yaisawarng, Journal of Banking and Finance 23.

Petersen, M.A., 1999. Comment on Jayaratne and Wolken, Journal of Banking and Finance 23.

Petersen, M.A., Rajan, R.G., 1994. The benefits of firm-creditor relationships: Evidence from small business data, Journal of Finance 49, 3-37.

Petersen, M.A., Rajan, R.G., 1995. The effect of credit market competition on lending relationships, Quarterly Journal of Economics 110, 407-443.

Pilloff, S.J., 1996. Performance changes and shareholder wealth creation associated with mergers of publicly traded banking institutions, Journal of Money, Credit, and Banking 28, 294-310.

Pilloff, S.J., 1997. Multimarket contact in banking, working paper, Board of Governors of the Federal Reserve System.

Pilloff, S.J., 1998. Does the presence of big banks influence competition in local markets?, working paper, Board of Governors of the Federal Reserve System.

Pilloff, S.J., Santomero, A.M., 1998. The value effects of bank mergers and acquisitions, edited by Y. Amihud and G. Miller, Bank Mergers \& Acquisitions, Kluwer Academic (Boston, MA), 59-78.

Prager, R.A., Hannan, T.H., 1999. Do substantial horizontal mergers generate significant price effects?, Evidence from the Banking Industry, Journal of Industrial Economics.

Prowse, S.D., 1997. Alternative methods of corporate control in commercial banks, Journal of Financial Research 20(4), 509-27.

Pulley, L., Humphrey, D., 1993. The role of fixed costs and cost complementarities in determining scope economies and the cost of narrow banking proposals, Journal of Business 66, 437-62.

Puri, M., 1996. Commercial banks in investment banking: Conflict of interest or certification Role? Journal of Financial Economics 40, 373-401.

Radecki, L.J., 1998. Small expanding geographic reach of retail banking markets, Federal Reserve Bank of New York Economic Policy Review 4, 15-34.

Radecki, L.J., Wenninger, J., Orlow, D.K., 1997. Industry structure: Electronic delivery's potential effects on retail banking, Journal of Retail Banking Services 19(4), 57-63.

Ramakrishnan, S., Thakor, A.V., 1984. Information reliability and a theory of financial intermediation, Review of Economic Studies 51, 415-432.

Resti, A., 1998. Regulation can foster mergers, can mergers foster efficiency? The Italian case, Journal of 
Economics and Business 50, 157-69.

Rhoades, S.A., 1985. Market share as a source of market power: Implications and some evidence, Journal of Economics and Business 37, 343-63.

Rhoades, S.A., 1986. The operating performance of acquired firms in banking before and after acquisition, Staff Economic Studies 149, Board of Governors of the Federal Reserve System, Washington, DC.

Rhoades, S.A., 1990. Billion dollar bank acquisitions: A note on the performance effects, working paper, Board of Governors of the Federal Reserve System, Washington, DC.

Rhoades, S.A., 1993. The efficiency effects of horizontal bank mergers, Journal of Banking and Finance 17, 411-22.

Rhoades, S.A., 1996. Bank mergers and industrywide structure, 1980-94, Board of Governors of the Federal Reserve System, staff study no. 169.

Rhoades, S.A., 1997. Have barriers to entry in retail commercial banking disappeared?, Antitrust Bulletin, 42, 997-1013.

Rhoades, S.A., 1998. The efficiency effects of bank mergers: An overview of case studies of nine mergers, Journal of Banking and Finance 22, 273-91.

Rochet, J.-C., Tirole, J., 1996. Interbank lending and systemic risk, Journal of Money, Credit and Banking $28,733-62$.

Rosen, R.J., 1999, Comment on DeYoung, Goldberg and White, Journal of Banking and Finance 23.

Rosen, R.J., Lloyd-Davies, P.R, Kwast, M.L., Humphrey, D.B., 1989. New banking powers: A portfolio analysis of bank investment in real estate, Journal of Banking and Finance 13, 355-366 .

Santos, J.A.C., 1998. Commercial banks in the securities business: A review, Bank for International Settlements working paper No. 56.

Sapienza, P., 1998. The effects of banking mergers on loan contracts, Northwestern University working paper.

Santomero, A.M., 1999. Bank mergers: What's a policymaker to do?, Journal of Banking and Finance 23.

Saunders, A., 1999. Consolidation and universal banking, Journal of Banking and Finance 23.

Saunders, A., Walter, I., 1994. Universal Banking in the United States. Oxford University Press, New York.

Saunders, A., Wilson, B.K., 1999. Bank capital and bank structure: A comparative analysis of the U.S., U.K., and Canada, Journal of Banking and Finance 23.

Savage, D.T., 1991. Mergers, branch closings, and cost savings, working paper, Board of Governors of the Federal Reserve System, Washington, DC.

Schranz, M., 1993. Takeovers improve firm performance: Evidence from the banking industry, Journal of 


$$
\mathrm{R}-16
$$

Political Economy 101, 299-326.

Shaffer, S., 1989. Competition in the U.S. banking industry, Economics Letters 29, 321-23.

Shaffer, S., 1993. Can megamergers improve bank efficiency? Journal of Banking and Finance 17, 423-36.

Sharpe, S. A., 1997. The effect of consumer switching costs on prices: A theory and its application to the bank deposit market, Review of Industrial Organization 12, 79-94.

Shepherd, W.G., 1986. Tobin's q and the structure-performance relationship: Comment, American Economic Review 76, 1205-10.

Shull, B., White, L.J., 1998. Of firewalls and subsidiaries: The right stuff for expanded bank activities, Journal of Banking Law.

Siems, T.F., 1996. Bank mergers and shareholder wealth: Evidence from 1995's megamerger deals, Financial Industry Studies, Federal Reserve Bank of Dallas, 1-12.

Simons, K., Stavins, J., 1998. Has antitrust policy in banking become obsolete? New England Economic Review, Federal Reserve Bank of Boston, 13-26.

Smirlock, M., 1985. Evidence on the (non) relationship between concentration and profitability in banking, Journal of Money, Credit, and Banking 17, 69-83.

Smirlock, M., Gilligan, T., Marshall, W., 1984. Tobin's q and the structure-performance relationship, American Economic Review 74, 1050-60.

Solomon, Elinor H., 1999. What should regulators do about consolidation and electronic money? Journal of Banking and Finance 23.

Sørensen, B.E., Yosha, O., 1997. International risk sharing and European monetary unification, working paper, Brown University.

Spindt, P.A., Tarhan, V., 1992. Are there synergies in bank mergers?, working paper, Tulane University, New Orleans, LA.

Srinivasan, A., 1992. Are there cost savings from bank mergers? Federal Reserve Bank of Atlanta Economic Review, 17-28.

Srinivasan, A., Wall, L.D., 1992. Cost savings associated with bank mergers, working paper, Federal Reserve Bank of Atlanta, Atlanta GA.

Strahan, P.E., Weston, J.P., 1996. Small business lending and bank consolidation: Is there cause for concern? current issues in Economics and Finance 2, Federal Reserve Bank of New York 2, 1-6.

Strahan, P.E., Weston J.P., 1998. Small business lending and the changing structure of the banking industry, Journal of Banking and Finance 22, 821-45.

Subrahmanyam, V., Rangan, N., Rosenstein, S., 1997. The role of outside directors in bank acquisitions, Financial Management 26(3), 23-36. 
Thakor, A.V., 1999. Information Technology and Financial Services Consolidation, Journal of Banking and Finance 23.

Thomas, K.H., 1998, The CRA Handbook (McGraw-Hill, New York).

Udell, G.F., 1999. Comment on Avery, Bostic, Calem and Canner, Journal of Banking and Finance 23.

Vander Vennet, R., 1996. The effect of mergers and acquisitions on the efficiency and profitability of EC Credit Institutions, Journal of Banking and Finance 20, 1531-58.

Vander Vennet, R., 1997. Determinants of EU bank takeovers: A logit analysis, mimeo, March 1997.

Walraven, N., 1997. Small business lending by banks involved in mergers, Finance and Economics Discussion Series 97-25, Board of Governors of the Federal Reserve.

Welch, I., 1997. Why is bank debt senior? A theory of asymmetry and claim priority based on influence costs, Review of Financial Studies 10, 1203-1236.

Wells, K., 1996. Are checks overused?, Federal Reserve Bank of Minneapolis Quarterly Review 20, 2-12.

Whalen, G., 1995. Out-of-state holding company affiliation and small business lending, Office of the Comptroller of the Currency, Economic and Policy Analysis working paper 95-4.

Whalen, G., 1997. The competitive implications of safety net-related subsidies, Office of the Comptroller of the Currency, Economics Working Paper 97-9.

Wheelock, D.C., Wilson, P.W., 1998. Why to banks disappear? The determinants of U.S. bank failures and acquisitions, mimeo, May 1998.

White, W., 1998. The coming transformation of continental European banking, Bank for International Settlements, Working Paper no. 54.

Williamson, O., 1967. The economics of defense contracting: incentives and performance in issues in Defense Economics, ed. R. McKean. New York: Columbia University Press.

Williamson, O., 1988. Corporate finance and corporate governance, Journal of Finance 43, 567-591.

Yuengert, A., 1993. The measurement of efficiency in life insurance: Estimates of a mixed normal-gamma error model, Journal of Banking and Finance 17, 483-96.

Zardkoohi, A., Kolari, J., 1997. The effect of structural changes in the U.S. banking industry on small business lending, working paper, Texas A\&M University.

Zhang, H., 1995. Wealth effects of U.S. bank takeovers, Applied Financial Economics 55, 329-36. 


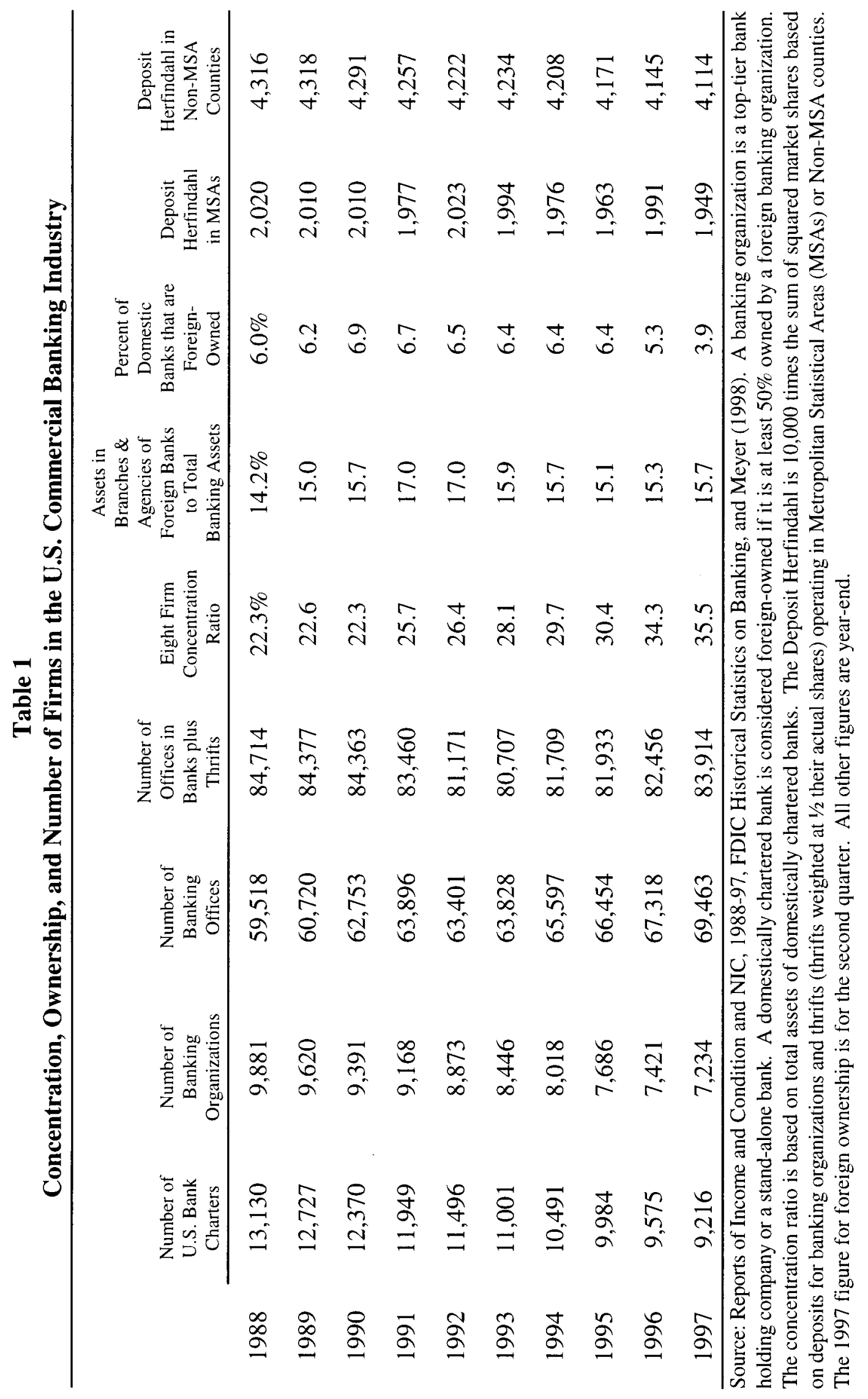


Table 2

M\&As, Failures, and Entry in the U.S. Commercial Banking Organizations

\begin{tabular}{|c|c|c|c|c|c|c|}
\hline & $M \& A$ & Unaffiliated & 3anking Org & iizations & & \\
\hline & Total & In-Market & $\begin{array}{c}\text { Market } \\
\text { Extension }\end{array}$ & $\begin{array}{c}\text { Mega- } \\
\text { Mergers } \\
\text { [Interstate] }\end{array}$ & $\begin{array}{l}\text { De Novo } \\
\text { Entry }\end{array}$ & Failures \\
\hline 1988 & 468 & 192 & 276 & $\begin{array}{c}14 \\
{[7]}\end{array}$ & 228 & 209 \\
\hline 1989 & 350 & 195 & 155 & $\begin{array}{c}3 \\
{[2]}\end{array}$ & 201 & 206 \\
\hline 1990 & 366 & 195 & 171 & $\begin{array}{c}6 \\
{[2]}\end{array}$ & 175 & 158 \\
\hline 1991 & 345 & 189 & 156 & $\begin{array}{c}16 \\
{[12]}\end{array}$ & 107 & 105 \\
\hline 1992 & 401 & 164 & 237 & $\begin{array}{c}23 \\
{[15]}\end{array}$ & 73 & 98 \\
\hline 1993 & 436 & 222 & 214 & $\begin{array}{c}15 \\
{[10]}\end{array}$ & 59 & 40 \\
\hline 1994 & 446 & 237 & 209 & $\begin{array}{c}15 \\
{[11]}\end{array}$ & 48 & 11 \\
\hline 1995 & 344 & 115 & 229 & $\begin{array}{c}20 \\
{[16]}\end{array}$ & 110 & 6 \\
\hline 1996 & 311 & 190 & 121 & $\begin{array}{c}26 \\
{[14]}\end{array}$ & 148 & 5 \\
\hline 1997 & 207 & $\mathrm{NA}$ & NA & $\begin{array}{c}15 \\
{[11]}\end{array}$ & 207 & 1 \\
\hline
\end{tabular}

Source: Rhoades (1996, Tables 4, 10, 18) and Meyer (1998). Figures for 1997 are estimated. Mergers are defined here as combinations that bring together under common ownership banks that had been independent. Mergers of affiliated banks are not included. When a multibank holding company is acquired, each commercial bank in that holding company is counted as a separate merger. Market extension mergers are defined as those where the target bank is located in a different market from the acquirer, where a market is defined as a Metropolitan Statistical Area (MSA) or non-MSA county. Both the target banking organization and the acquiring banking organization must have total assets over $\$ 1$ billion to be considered a megamerger. 


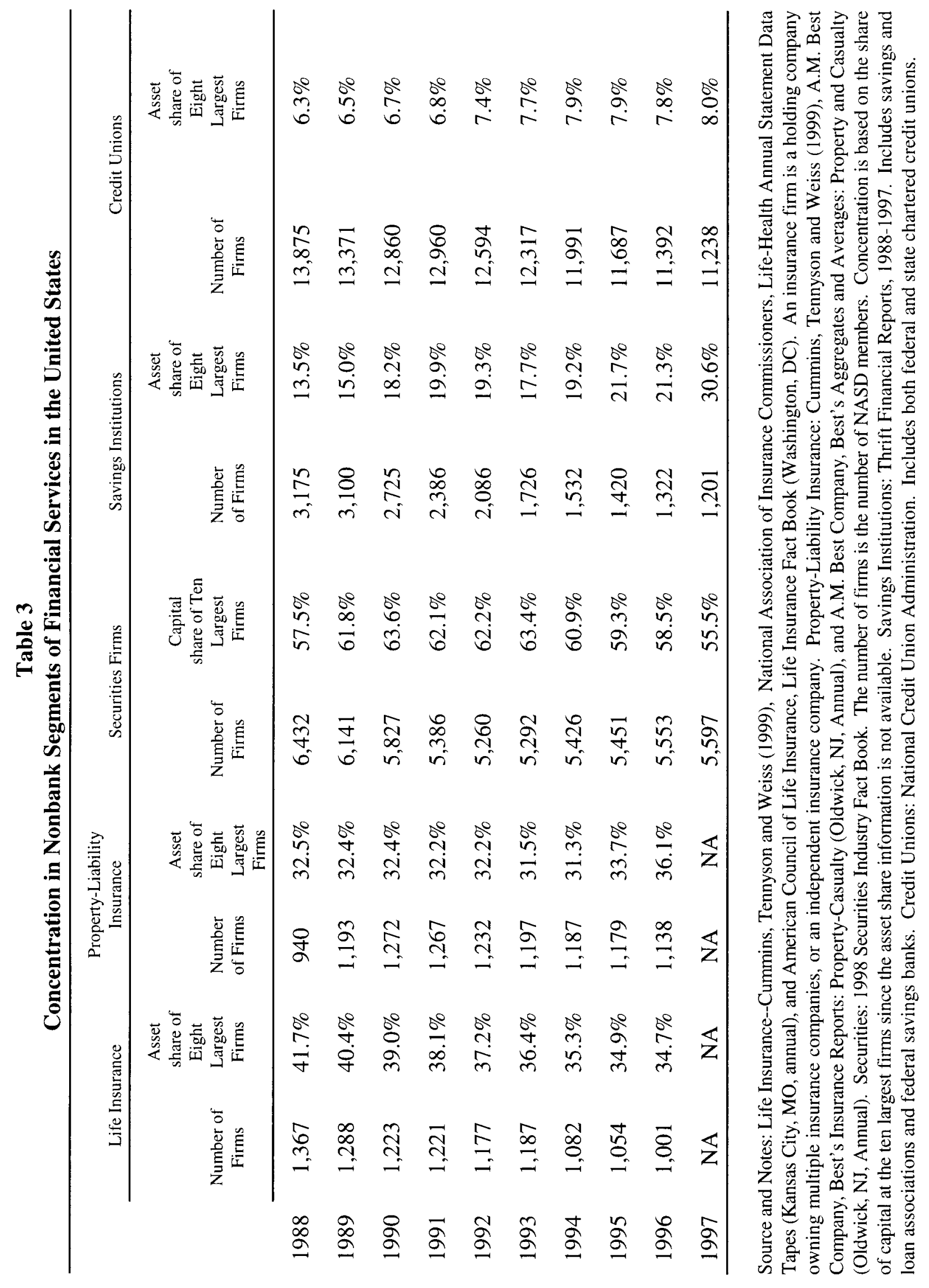



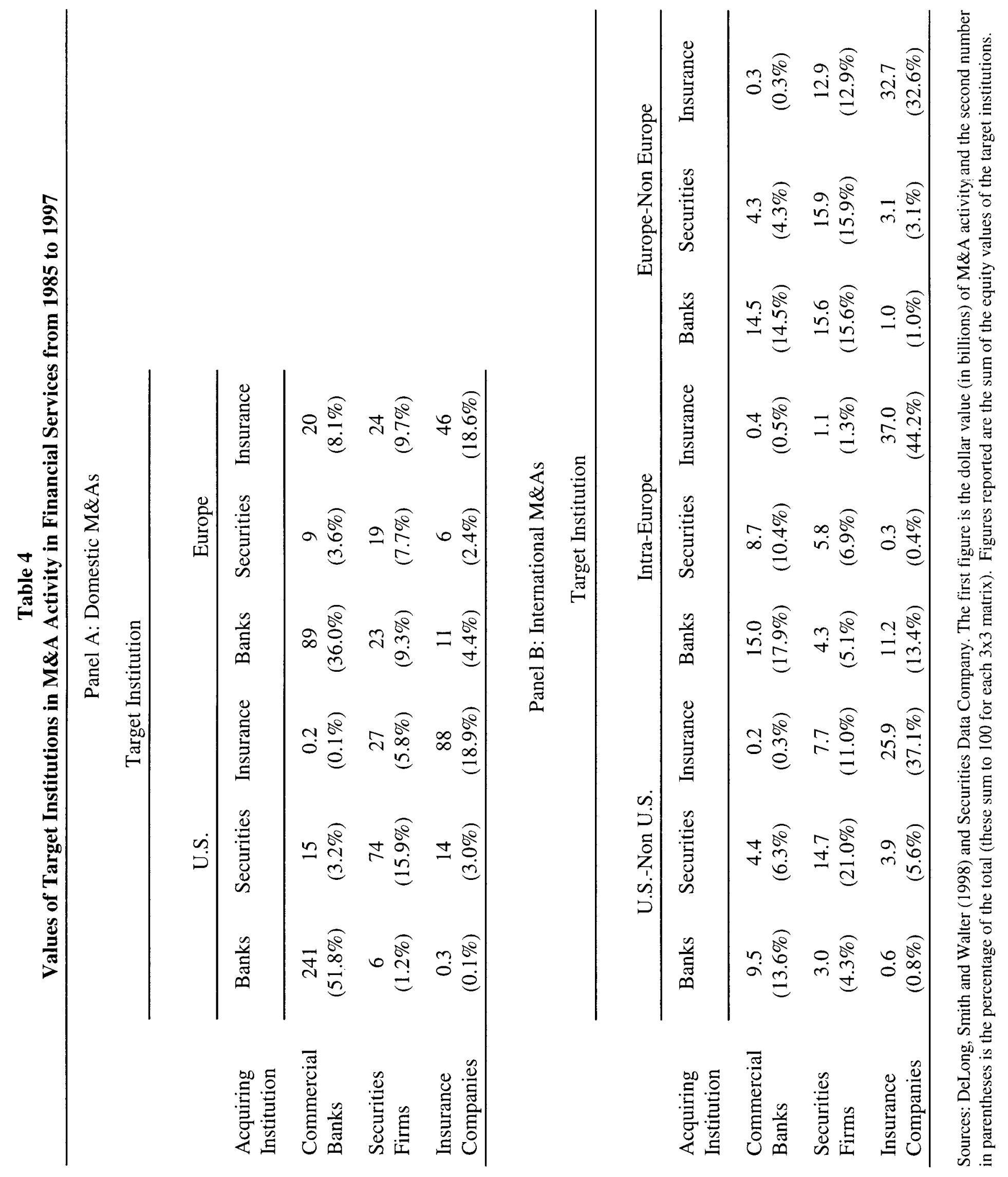
Table 5

Depository Institutions and Offices in the Group of Ten Countries 1996

\begin{tabular}{lcccc} 
& $\begin{array}{c}\text { Number of } \\
\text { Institutions }\end{array}$ & $\begin{array}{c}\text { Number of } \\
\text { Offices }\end{array}$ & $\begin{array}{c}\text { Number of } \\
\text { Inhabitants } \\
\text { Per Office }\end{array}$ & $\begin{array}{c}\text { Number of Offices } \\
\text { Per Institution }\end{array}$ \\
\cline { 2 - 5 } Belgium & 143 & 9,464 & 1,075 & 66.2 \\
Canada & 2,497 & 16,209 & 1,857 & 6.5 \\
France & 547 & 47,263 & 1,238 & 86.4 \\
Germany & 3,509 & 70,118 & 1,169 & 20.0 \\
Italy & 939 & 40,030 & 1,436 & 42.6 \\
Japan & 4,635 & 77,013 & 1,634 & 16.6 \\
Netherlands & 126 & 6,820 & 2,277 & 54.1 \\
Sweden & 125 & 3,859 & 2,291 & 30.9 \\
Switzerland & 372 & 7,512 & 946 & 20.2 \\
United Kingdom & 561 & 36,507 & 1,611 & 65.1 \\
United States & 23,123 & 95,777 & 2,772 & 4.1 \\
\hline
\end{tabular}

Source: Statistics on Payment Systems in the Group of Ten Countries, Bank for International Settlements, December 1997. The number of offices for the U.S. includes commercial banks, thrifts, and credit union 